
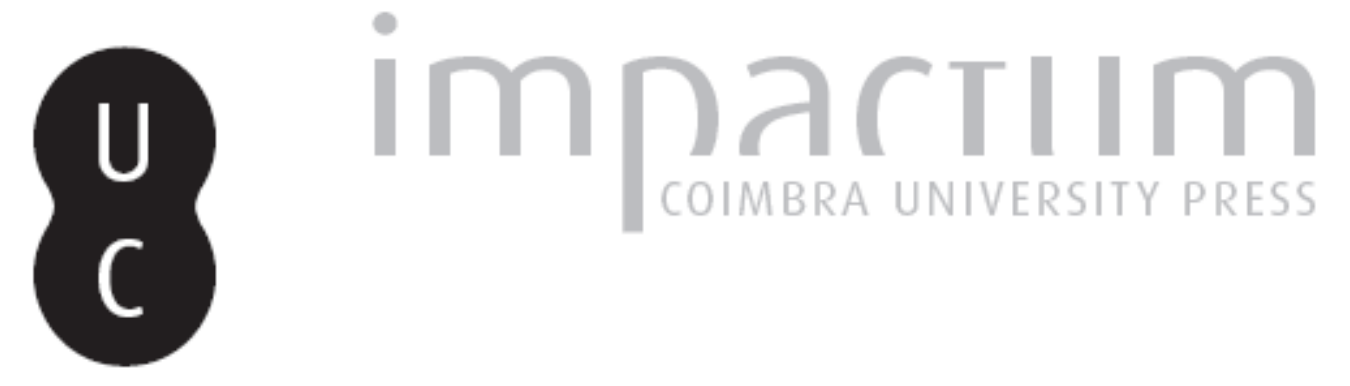

\title{
De Gil Vicente a Camões: culturas e mentalidades
}

\section{Autor(es): Dias, Graça Silva}

Publicado por: Imprensa da Universidade de Coimbra

URL persistente:

URI:http://hdl.handle.net/10316.2/43961

DOI:

DOl:https://doi.org/10.14195/2183-8925_2_8

Accessed : $\quad$ 26-Apr-2023 13:22:15

A navegação consulta e descarregamento dos títulos inseridos nas Bibliotecas Digitais UC Digitalis, UC Pombalina e UC Impactum, pressupõem a aceitação plena e sem reservas dos Termos e Condições de Uso destas Bibliotecas Digitais, disponíveis em https://digitalis.uc.pt/pt-pt/termos.

Conforme exposto nos referidos Termos e Condições de Uso, o descarregamento de títulos de acesso restrito requer uma licença válida de autorização devendo o utilizador aceder ao(s) documento(s) a partir de um endereço de IP da instituição detentora da supramencionada licença.

Ao utilizador é apenas permitido o descarregamento para uso pessoal, pelo que o emprego do(s) título(s) descarregado(s) para outro fim, designadamente comercial, carece de autorização do respetivo autor ou editor da obra.

Na medida em que todas as obras da UC Digitalis se encontram protegidas pelo Código do Direito de Autor e Direitos Conexos e demais legislação aplicável, toda a cópia, parcial ou total, deste documento, nos casos em que é legalmente admitida, deverá conter ou fazer-se acompanhar por este aviso. 
INSTITUTO DE HISTÓRIA E TEORIA DAS IDEIAS

\title{
REVISTA DE HISTÓRIA $D A S$ IDEIAS
}

\author{
VOL. II
}

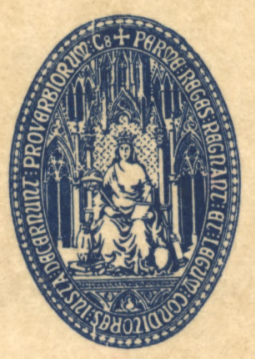

UNIVERSIDADE DE COIMBRA

$1978-1979$ 


\title{
DE GIL VICENTE A CAMÕES
}

\author{
CULTURAS E MENTALIDADES *
}

1. Costuma considerar-se o tempo social em que determinada pessoa vive aquele que decorre do seu nascimento à sua morte. Todavia, ao vir ao mundo, ela encontra uma sociedade instalada e esta imprime-lhe a primeira e muito profunda marca. O mundo dos seus pais acompanha-a até à emancipação cultural, mais precoce ou mais tardia, mas que podemos situar no dealbar da juventude. O homem nasce, pois, culturalmente antes de nascer fisicamente.

Neste trabalho, privilegiamos aqueles sinais dos tempos, indicativos de mudanças na mentalidade sociocultural. Mudanças que, para além da «vulgata, do denominador comum da época» (na expressão de Philippe Ariès), revelam ou veleidades sem amanhã ou anúncios com frutificações. Mudanças que, já incidindo sobre as estruturas, se afiguram aos contemporâneos oscilações conjunturais que abalam um pouco o edifício, mas não o fazem ruir. Dir-se-ia que são apenas fumos da India, ambições vãs, heresias...

Ao escolher Gil Vicente como testemunha desta época de crise, tem-se plena consciência da acusação de sociologismo (no sentido pejorativo) que a maioria dos estudiosos da literatura, que se apoderam dos escritores como objecto de dissecação, nos irão possivelmente assacar. Todavia, corre-se $o$ risco na exacta consciência de que o artista pinta o real, nega $o$ real e idealiza $o$ real - mas o referente é sempre o real.

2. O teatro apresenta, como toda a obra de arte, uma certa imagem da sociedade, não podendo, porém, reduzir-se ao somatório dos

* Texto alargado da comunicação apresentada ao colóquio The portuguese world in the time of Camões, realizado na Universidade da Flórida (Gainesville), em 29-30 de Setembro e 1 de Outubro de 1980. 
dados sociais. Não se nega assim a originalidade da visão pessoal do dramaturgo, mas tem-se em conta que esta traduz uma representação do mundo inserida nos esquemas de cultura prevalecentes no seu tempo. A linha de pensamento do artista só pode definir-se, portanto, em relação à ideologia dominante, mesmo quando (o que acontece frequentemente) a contesta. Não existe uma imagem objectiva da sociedade - só possível graças ao distanciamento histórico - , porque o artista vê os homens sub specie artis, não sub specie aeternitatis. A sua visão é, contudo, colorida pelas suas conviç̧̃̃es - fé religiosa, adesão política, interesses de classe. Depende também de um público (ou até de um mecenas, v. g. no século XVI), embora procure preservar a independência possível pelo recurso, mais ou menos conseguido, à ambiguidade da escrita.

3. Estas considerações permitem-nos uma aproximação intelectiva da tão decantada antinomia entre teatro como documento social e teatro como obra de arte, e fazer a sua superação. Porque o autor que atinge um determinado nível artístico é forçado a instaurar um debate entre vozes, que o mesmo é dizer, entre paixões e vontades opostas. Os personagens (que não títeres) escapam, por assim dizer, ao seu criador e, para serem autênticos, terão de ter a possibilidade de se exprimir.

\section{PROGNÓSTICOS «VERSUS» PROFECIAS}

4. Elegendo um determinado auto de Gil Vicente como local privilegiado de observação - o auto geralmente denominado de Mofina Mendes -, determinamo-nos por um certo número de razões. Em primeiro lugar, porque nesse auto se abordam três grandes temas da problemática sociocultural europeia da época: a voga dos prognósticos (versus profecias); a questão guerra justa - guerra injusta (levantada pelos confrontos entre as potências cristãs); a emancipação do campesinato assalariado. Estes sinais anunciadores de novos tempos eram lidos, no Portugal de princípios/meados do século XVI, em termos de apocalipse, por porem em causa toda uma estrutura social.

Em segundo lugar, porque grandes linhas de uma «forma mentis» em crise - a concepção da vida e da morte, do futuro e do tempo - estão presentes (mesmo in absentia) neste auto exemplar que é também, quanto a nós, o Auto da Subversão. 
5. Abre o auto com uma fala «a modo de pregação», feita por um frade "sandeu», o qual, usando de um processo de distinções escolásticas, se enreda numa série de referências, citações, reservas, interrupções, numa argumentação absurda, só comparável à célebre arenga do mestre Janotus de Bragmardo rabelaiseano. Sem dúvida que se está perante uma paródia que visa atingir uma escolástica decadente, que teimava em sobreviver. Não menos importante se nos afigura, entretanto, a utilização do frade-bobo para a veiculação do ponto de vista do autor em relação aos prognósticos (1). Não era a primeira vez que mestre Gil arremetia contra as artes divinatórias, e não era, além disso, o único a fazê-lo. No Auto dos Físicos (1524), através do físico Torres (personagem que corresponde a uma personalidade real), certa medicina que fazia depender os tratamentos da conjunção, favorável ou desfavorável, dos astros era atingida (2). No Auto da Feira, (1527) (3), Mercúrio, apresentador da peça, faz a «charge» dos processos divinatórios, baseados na leitura astronómica. E Garcia de Resende também ergue a voz contra a praga das predições: «Vimos

(1) Explicitamente, nos seguintes passos: «.... não vos enganeis, / letrados de rio torto, / que o porvir não no sabeis, / e quem nisso quer pôr peis / tem cabeça de minhoto; / ó bruto animal da serra, / ó terra filha do barro, / como sabes tu, bebarro, / quando há-de tremer a terra, / que espantas os bois e o carro / .... Ricardus, Ilarius, Remigius / dizem, convem a saber: / se tens prenha tua mulher, / e per ti o composeste, / queria de ti entender / em que hora há-de nascer, / ou que feições há-de ter/esse filho que fizeste. / Não no sabes: quanto mais / cometerdes falsa guerra, / presumindo que alcançais / os secretos divinais/que estão debaixo da terra» (Gil Vicente, Auto da Mofina Mendes, in "Obras Completas», ed. Sá da Costa, vol. 1. ${ }^{\circ}$, pp. 129-131).

(2) Eis um passo do diagnóstico do físico: «.... E também deste ajuntamento / dos planetas desta era.../ não sei... não sei... mas per mera / estrolomia... não sei, eu sento... / não sei que é, nem que era;/mas há-de saber quem cura / os passos que dá uma estrela / e há-de sangrar por ela, / e há-de saber julgar / as águas n'uma panela....» (GIL VicenTe, Auto dos Fisicos, in «Idem», vol. 6. ${ }^{\circ}$, pp. 120-121).

(3) Mercúrio diz: «....E porque a estronomia / anda agora mui maneira, / mal sabida e lisongeira, / eu à honra deste dia / vos direi a verdadeira. / Muitos presumem saber / as operações dos ceus, / e que morte hão de morrer, / e o que há-de acontecer/aos anjos e a Deus, / e ao mundo e ao diabo. / E que o sabem tem por fé; / e eles todos em cabo / terão um cão pelo rabo, / e não sabem cujo é. / E cada um sabe o que monta / nas estrelas que olhou, / e ao moço que mandou, / não lhe sabe tomar conta / de um vintem que lhe entregou. / Porém quero-vos pregar, / sem mentiras nem cautelas,/o que per curso de estrelas / se poderá adivinhar, / pois no ceu nasci com elas....” (Idem, vol. $1 .^{\circ}$, pp. 186-87). 
a astrologia / mentir toda em todo o mundo, / que toda a gente dizia / que em vinte e quatro havia / de haver dilúvio segundo; / e seco vimos o ano / e bem claro o engano / em que astrólogos estavam, / pois dantes tanto afirmavam/por chuvas haver grão dano»(1). Já mais para trás, um Estevão da Guarda troçava de «Martin Vásquez da astrologia» que "perdeu feúza, polo grand'engano dos planetas....»(2).

6. Antes de nos determos sobre o fenómeno, na sua incidência e na sua semiologia, impõe-se uma breve análise à enumeração de autores ou de obras feita no discurso do frade. Destacaremos alguns nomes: Orígenes, autoridade para os escritores do século XVI que se ocupam de prodígios e sua interpretação; Plínio (quer o Moço quer o Velho), autor de obras sobre portenta e mirabilia; Cícero, que escreveu De devinatione, livro tantas vezes reeditado no decurso de Quinhentos; Beda, o Venerável, que propõe uma meteorologia divinatória, adaptada, contudo, aos cânones de uma sociedade cristã. Outro nome a pôr em relevo: Quinto-Cúrcio, autor do De rebus Alexandri Magni, traduzido para francês (primeira tradução em francês de Quinto-Cúrcio, note-se) pelo humanista português Vasco de Lucena, sob o título de Faictz et gestes d'Alexandre le Grand(3), em 1468; Tomás, com muita probabilidade o santo de Aquino, embora não seja de excluir uma voluntária sobreposição de imagens e se visar, simultaneamente, Tomás de Catimpré, autor tão consultado pelos cultores da leitura dos signos,

(1) Garcia de Resende, Miscelânea, apud Crónica de Dom João II e Miscelânea, ed. Imprensa Nacional - Casa da Moeda, Lisboa, 1973, p. 371.

(2) M. Rodriguts LAPA, Colectânea de cantigas de escárneo e mal-dizer dos cancioneiros medievais galego-portugueses, ed. Galáxia, Lisboa, 1965, p. 196.

(3) Não confundir este «estrangeirado» com o seu quase homónimo e contemporâneo Vasco Fernandes de Lucena, guarda-mor da Torre do Tombo, antecessor de Rui de Pina. O humanista Vasco de Lucena viveu na corte de Borgonha e foi a Carlos, o Temerário, que dedicou a obra referida. O duque parece ter tido a obra em tanto apreço que fez dela o seu livro de cabeceira. O escritor lusitano possuía já uma notável capacidade crítica que o faz rejeitar a mitificação dos heróis. Assim, omitiu, na sua tradução, as narrativas de feitos fantasiosos atribuídos a Alexandre (elevação pelos ares ou descida à profundeza dos mares, por exemplo), por constituirem apenas «fábulas inventadas por homens ignorantes da natureza das coisas» (cit. por JEAN CÉARD, La nature et les prodiges, Genéve, Droz, 1977, p. 59). Pode discutir-se, evidentemente, a licitude dos cortes, da parte de um tradutor. O que não pode negar-se é que nos encontramos perante uma concepção do conhecimento que repudia a inverosimilhança. 
em especial pela sua obra Liber de natura rerum (Liber de monstruosis hominibus orientis se intitula a $3 .^{\mathrm{a}}$ parte). Santo Agostinho também surge na enumeração do pregador vicentino, o que não destoa, sabendo-se que na Cidade de Deus ocupam lugar de destaque as lendas de raças monstruosas numa óptica providencialista. Ponto de vista, aliás, não inteiramente partilhado por Isidoro de Sevilha, defensor de uma lei da simetria ou coincidentia oppositorum. Este erudito não é explicitamente indicado pelo nome, mas a referência faz-se indirectamente pelo título abreviado e um tanto (propositadamente) deturpado - Vandaliarum por Vandalorum - da sua História dos Vândalos e dos Suevos. No entanto, era às Etymologias que a maioria dos interessados pelos portenta ia buscar as bases para as suas especulações. Indicamos (sem esgotar a lista) só mais um nome: S. Jerónimo, autor da Vita Pauli Eremitae, também obra de consulta dos curiosos pela decifração dos mistérios da natureza (1).

Gil Vicente situa-se, portanto, dentro da sua época, ao ocupar-se e ao tomar posição nesta problemática. Se os monstros, como seres disformes ou raças à parte, não parece terem-no particularmente interessado, já os prodígios - como alteração à ordem da natureza - no seu aproveitamento para um sistema de antevisão do futuro, solicitam a sua atenção de homem social e homem cristão.

7. Na Europa de meados de Quinhentos, os litterati recorrendo (desenterrando, poder-se-ia dizer) aos mestres naturalistas da Antiguidade (os que o frade sandeu cita e muitos outros) lançam-se na produção de inúmeros De prodigiis ou De ostentis, que inundam o mundo intelectual (2). Não se destinavam essas obras exclusivamente aos grandes eruditos, mas aos homens de uma cultura média. Estes escritores quinhentistas funcionaram como intermediários entre o pensamento dos antigos (dos clássicos) e um auditório contemporâneo que não tinha acesso directo a tais fontes de informação. De início, processa-se, apenas, a transmissão do saber - que reflecte, aliás, uma

(1) Cfr. Gil Vicente, Auto de Mofina Mendes, «Idem», vol. 1.º, pp. 128-131.

(2) Citem-se, entre outros: o De prodigiis de Júlio Obsequens, largo reportório de prodígios autênticos, cuja 1.a edição é de 1508 , conhecendo sucessivas reedições - Basileia, 1514, Florença, 1515, Veneza, 1518, Basileia, 1521, Paris, 1528; outro De prodigiis, da autoria de Polydore Vergile, aparece em 1531; em 1532, Joachim Camerarius dá à estampa um De ostentis. 
visão da História, concebida como "series temporum» (ou «catena temporum»). Mas a actualização, fruto de uma outra visão histórica, a da descontinuidade (1), começa a inspirar, em maior ou menor grau, esses escritos, dependente do nível crítico do tradutor, adaptador ou comentador. O caso do nosso humanista Vasco de Lucena é paradigmático (2). Este tipo de literatura sofre um processo de vulgarização ao nível de uma camada mais extensa de público, não deixando de coexistir com os tratados de índole científica. Não confundir, porém, uma literatura popular (no sentido de difusão) paródica - como a Grande Pronostication e L'énigme en prophétie, que se atribuem a Rabelais e a Mellin de Saint-Gellais, respectivamente - e uma literatura futurológica que se reclamava de «séria». A este grupo pertencem os almanaques (borda-de-água ou folhinhas, como se vieram a chamar entre nós) (3). Dirigidos primordialmente à gente do campo, incluíam, além das predições sobre o tempo (meteorológico) e a agricultura (sementeiras, colheitas) observaçð̃es menos inócuas. Os seus consumidores possuíam, decerto, uma mentalidade muito afim da de um João da Murtinheira da Romagem de Agravados que verbera Deus porque Ele permite o descontrolo dos elementos, sem os ajustar aos interesses de cada um. E exclama: «.... chove quando não quero / e faz um sol das estrelas / quando chuva alguma espero / ora alaga o semeado / ora seca quanto hi é / ora venta sem recado / ora neva e mata o gado / e ele [Deus] tanto se lhe dá» (4). Aplicando ao caso a feliz expressão de Geneviève Bollème, semelhante Deus não é o da religião, mas o dos almanaques. Mas estes não se limitavam a atribuir ao Criador a distribuição da chuva no campo e do sol na eira. Veiculavam também prognósticos que, começando por ser apenas interpretação dos sinais naturais (como o faziam marinheiros, médi-

(1) Um dos teorizadores da noção histórica de ruptura foi Loys Le Roy. O seu livro De la vicissitude ou variété des choses en l'univers, Paris, Pierre l'Huilier, 1575, constitui um marco na historiografia. Teve sucessivas reedições em francês: 1576, 1579, 1583, 1584. Em língua italiana, destacam-se, no século XVI, as edições de 1585 e 1592 . Foi traduzido a primeira vez, em inglês, em 1594.

(2) Vid. supra, p. 358.

(3) Em França, sob o nome genérico de Prognostications des laboureurs, compreende-se toda essa literatura, estudada por Geneviève Bollème, Robert Mandrou e outros.

(4) Gil Vicente, Romagem de Agravados in "Obras Completas», ed. Sá da Costa, vol. 5. ${ }^{\circ}$, p. 6. 
cos e agricultores), vão transmitir uma «filosofia» própria. Por norma, inculcavam ao leitor a ideia de que os prodígios eram preságios - sinais de que Deus se servia para advertir os mortais. Todavia, ao pôrem em causa a existência de astros especiais para reis, papas, grandes senhores e o comum dos mortais - «democratizando» os astros - apontavam numa direcção perigosa para os governantes. Não seria o naufrágio total da hierarquia, mas implicava, pelo menos, uma transformação profunda da sociedade.

8. Os dados que temos vindo a apontar levam, na sua correlação com a escrita vicentina, a admitir duas vias de acesso do dramaturgo à polémica desencadeada por toda a Europa em torno da questão dos «mirabilia» e sua leitura. Uma das vias seria o conhecimento das fontes literárias (ou pelo menos de obras de divulgação). Gil Vicente - disso é amostra a listagem de nomes enunciada pelo frade sandeu conhece os inspiradores, mais ou menos seguidos ou aproveitados, da literatura de prognósticos. Mas o mestre Gil que, em 1524, no Auto dos Físicos, troçava um tanto risonhamente, dos médicos devotos da astrologia judiciária, já em 1527 (Auto da Feira) manda Mercúrio - mensageiro dos deuses e de... Deus - invectivar os «clérigos e frades [que] já não têm. ao céu respeito» (1) e se põem a discorrer sobre os acontecimentos a vir. A sucessão dos abalos telúricos por toda a Europa, inclusive Portugal, tinha alarmado o comum dos mortais e originado especulações fantasiosas em espíritos semi-cultos (e até nos homens ilustrados, como Garcia de Resende, gerou uma certa perplexidade) (2).

(1) Vid. Auto da Feira, in «Idem", Vol. 1. ${ }^{\circ}$, p. 199.

(2) Do registo dos acontecimentos dos anos 1530-1531, feito por Garcia de Resende, na Miscelânea, destacamos os «mirabilia»: mula parida; menino de vinte e dois meses a falar e discorrer como gente grande (ao qual o autor aplica, muito justamente, a designação de "monstro»); e os fenómenos cósmicos: o cometa, as cheias do Tibre e o tremor de terra da Estremadura. Sobre este, Garcia de Resende não deixa de aludir à voz corrente: «Segundo todos diziam, / não foi cousa natural / o dano que recebiam / mas por castigo o haviam / e temiam vir mais mal». E prossegue: «muitas procissões fizeram, / e grandes esmolas deram, / e o Papa a todos deu / por confissão jubileu, / só porque a Deus temeram». E mais adiante torna a referir como o pavor das repetições aproximava as pessoas de Deus: «bradando por Deus eterno:/ todos logo confessados, / casos grandes perdoados, / feitas grandes devoções, / romarias, procissões, / em esmolas ocupados». Vid. Miscelânea, pp. 378-80. Deve notar-se que a Miscelânea corresponde já a uma menta- 
Mas a amplitude do sismo de 1531 vai reflectir-se em termos de visionarismo apocalíptico, nos «letrados de rio torto» que, pelos atributos e acessórios de que o artista os dota - «bruto animal da serra» e «bebarro» - são os frades de Santarém ou os numerosíssimos clérigos da Beira ( $\left.{ }^{1}\right)$.

9. O sermão dirigido ficticiamente aos frades de Santarém (na Carta a D. João III) constitui um ataque directo aos exploradores fanáticos do impacto produzido, entre a população, pelo tremor de terra. Três anos mais tarde, mestre Gil julga necessário retomar o assunto, não já em defesa de uma minoria perseguida, mas em nome da inteligência e da fé que considera lesadas com a actuação de falsos profetas. Enquadra, contudo, a matéria numa problemática mais vasta, porque, como irá ver-se, prognósticos e levantamentos político-sociais têm, para Gil Vicente e muitos dos seus contemporâneos,

lidade característica do século XVI, que irá afirmar-se com mais vigor pelos fins da centúria: o prazer de contar - a narração do «fait-divers», resvalando para uma literatura popular. Por outras palavras, os segredos da natureza, que até então interessaram a gente culta, caem na vulgarização: começa a ir-se ao encontro de uma curiosidade pública. $O$ público mostra uma sofreguidão, uma necessidade de alimentar a imaginação - até aí satisfeita com velhos romances de cavalaria ou liturgias religiosas. As narrativas de prodígios, em geral acompanhadas de reflexões sentenciosas, de moralização - caso da Miscelânea - estão já a responder a um mercado, a uma sociedade de consumo. Aos poucos, despem-se do aparelho "filosófico» e passam a ficticizar-se, isto é, a fazer aderir o leitor a um mundo fictício. $O$ escritor deste género de literatura pretende convencer o leitor da existência dos factos que relata, dos personagens que encarnam esses factos, e o leitor pretende ser convencido. Ao instruir e edificar, o narrador já está a prender e a distrair: objectivo, portanto, de uma sociedade consumista. Será por meados/fins do século XVIII que, ao atingir-se um certo grau de saturação, se procurará uma verosimilhança que não se coaduna com o extraordinário.

(1) Vid. Auto da Mofina Mendes, in «Idem», vol. $1 .^{\circ}$, p. 129. Também pode incluir-se nesta galeria o clérigo que Anrique da Mota põe a carpir pela perda de uma pipa de vinho: «Ó vinho, quem te perdera / primeiro que te comprara! / Ó quem nunca te provara/ou provando-te morrera! / $\delta$ quem nunca fora nado/ neste mundo, / pois vejo tão mal logrado / um tal bem, / tão estimado, / tão profundo!», Os lamentos, com acompanhamento dos amigos, inclusive do vigário, prosseguem. Vid. Cancioneiro Geral de Garcia de Resende, vol. 2. ${ }^{\circ}$, ed. do Centro de Estudos Românicos, Coimbra, 1973, pp. 253-255. 
uma raiz comum: a subversão de valores tidos como perenes - e que eram históricos (1).

Uma das pedras de escândalo, para o cristão rigoroso que era Gil Vicente, residia na utilização do prestígio que o múnus pastoral conferia aos clérigos para um autêntico terrorismo profético. Ousavam mesmo invocar a autoridade dos santos e das próprias Escrituras nas suas leituras dos fenómenos cósmicos. Já o concílio de Agde, no século VI, via nessas leituras proféticas manhas diabólicas (2). No século XVI, com a escalada das adivinhações pelos preságios, augúrios, sortes e astros, assiste-se também a um «crescendo» de condenações conciliares e papais. Os concílios que mais veementemente se manifestam contra a identificação do falso profeta com o autêntico, são o de Milão (1565) e o de Toulouse (1590), culminando a censura com o solene anátema de Sisto V.

10. Se Gil Vicente condena os prognósticos, enquanto falsas profecias, admite e reverencia as profecias autenticadas. Aliás, já no Auto de Sibila Cassandra o poeta contrapõe a insensatez da interpretação do futuro, não inspirada pelo espírito divino, à que é avalizada por ele. No Auto da Mofina Mendes, o autor é mais explícito, pois as damas da Virgem - Prudência, Pobreza, Humildade e Fé são as leitoras das visões antecipatórias das profetizas do Velho Testamento. Por outras palavras, constituem as virtudes que devem ornar o profeta autêntico.

Este ponto afigura-se-nos de grande relevância para o estudo da mentalidade da época, abrindo pistas pouco exploradas entre nós. Gil Vicente, ao condenar os falsos profetas, insere-se dentro da mais estrita ortodoxia. Contudo, nesta Idade Média atardada a que ele,

(1) São as «novas novidades e mudanças» de que fala ainda Garcia de Resende, as quais o homem só poderá enfrentar se «amar Deus de coração / e servi-lo de vontade» porque "Deus tem o poder, / ele só é que o sabe, / ninguém pode compreender / seus juizos e saber / e poder que nele cabe». E, assim, com esta memória do passado, pelo qual o porvir se modela («que o porvir é o passado»), se propõe o autor chegar à grande questão: quem é o homem («Ver quem sam»), para que nasceu ("Como [= para que] nasci»).

(2) «Student auguriis, et sub nomine fictae religionis per eas, quas sanctorum sortes vocant, divinationis scientiam profitentur, aut quarumcumque scripturarum inspectione futura promittunt» (canon 42). Vid. «Dictionnaire de Théologie Catholique», fasc. XXVI, Paris, 1908, pp. 1442-1445. 
em parte, ainda pertence, os valores religiosos dobram-se de valores sociais. Os mercimonia inhonesta não designavam apenas aquelas categorias profissionais ligadas ao sangue e à sujidade. Designavam também as actividades dos negociantes, não só por o dinheiro poder incluir-se na sujidade, mas porque vendiam o tempo - estabelecendo prazos, por exemplo. Ora os arautos e divulgadores dos prognósticos incorrem no mesmo pecado: transacionam com o tempo e, mais, utilizam, sem para isso terem delegação divina, a ciência. Tempo e Ciência eram, no esquema teológico medievo, dois atributos ou monopólios do Criador (1).

\section{O PASTOR CONFORMISTA}

10. Na sequência do Auto da Mofina Mendes, à cena da Anunciação (na qual, por agora, não nos deteremos) segue-se a cena pastoril.

Logo ao entrar em cena, o pastor André, tomando o público por confidente, exprime a sua inquietação pelo desaparecimento de uma burra. O motivo do extravio dos animais, tão glosado por Gil Vicente (2), traduz uma situação muito concreta, é um reflexo muito directo do real. André receia, e o receio tem fundamento, que a burra se tenha introduzido em terras de cultivo, o que lhe poderia acarretar dissabores (3).

Embora já neste tempo os proprietários andassem a vedar os pastos, o sistema não estava ainda generalizado e dava lugar a toda

(1) Isto explica a desconfiança de que eram alvo (e até uma certa marginalização) os homens de lei e os professores laicos. Ambos vendiam a palavra, porque os segundos, fora das escolas monásticas e sem as prebendas canónicas, só poderiam subsistir com as gratificações dos alunos. $\mathrm{O}$ assalto dos intelectuais aos direitos de cidade é já renascentista.

(2) Gregório (do Auto dos Reis Magos) não sabe «parte ni recado del ganado» e o seu companheiro, Valério, quando se distrai a cortejar pastoras, deixa «entrar el ganado en lo vedado", o que também acontece a Lucas (Auto Pastoril Castelhano) que põe o seu interesse pelos bailados de Marta acima do seu dever de pastor zelozo. Na Tragédia Pastoril da Serra de Estrela, Felipa procura o gado, Catarina perdeu, pelo menos, uma novilha e Fernando, na esteira dos outros apaixonados, não dá conta que o gado vai ao trigo, quando está enlevado com a sua namorada.

(3) «.... e foi-se a pascer folhada: / porque besta despeada, / não pace nos sovereiros» (Auto da Mofina Mendes, «Idem», vol. 1. ${ }^{\circ}$, p. 142). 
uma série de queixas, rixas e atritos, de que documentos da época se fazem eco, e que mostram bem as tensões existentes entre as diversas camadas da população rural.

Na segunda metade do século XV, o presidente da Casa da Suplicação, Rui Gomes de Alvarenga, queixa-se ao rei de que, na sua propriedade de Santarém, uos gados e outros animais... fazem muito dano ao trigo, oliveiras, vinhas e hortas da quinta» (1). Mais ou menos pela mesma altura, refere-se numa representação às cortes que «as veaç̧ões alimarias.... danam e comem vinhas e os pães....» (2). Não entrando nos meandros desta guerrilha, anote-se apenas que ora um, ora outro dos contendores, levou vantagem. A balança nem sempre pendeu para o lado devido, mas inclinou-se segundo o peso da fracção das classes dominantes que, no momento, detinha a hegemonia.

Outro dado nos fornece a fala de André. A burra levava os utensílios artesanais e «dois sacos de pães inteiros, porros, cebolas e alhos». Era a alimentação do dia. A nossa população rural também recorria a sucedâneos do pão, como a castanha e a bolota, mas a ementa do assalariado ou rendeiro não fugia muito a este padrão. Acontece até que outros produtos, colhidos «in loco», conseguiam minorar a frugalidade da refeição, pois, segundo Damião de Góis, a nossa gente do campo podia sustentar-se, quase todo o ano, «lautamente [sic] de frutos silvestres, mel e ervas» (3). Todavia cumpre dizer que o huma-

(1) Carta régia de 8 de Abril de 1462, reproduzida, parcialmente, por CostA Lово, História da sociedade em Portugal no século $X V$, Lisboa, Imprensa Nacional, 1904, p. 99. Também em Espanha pastores e agricultores se digladiavam, pelo mesmo motivo: os prejuízos causados pelo gado nas terras cultivadas. Cfr. Historia de España y America, t. 2.0 (Baja Edad Media), pp. 228 ss.

(2) Excerptos dos capitulos gerais das Cortes: Cortes de Lisboa em 1459, in C. Lово, ob. cit., p. 587.

(3) «.... cujus [Hispaniae] ubertas tanta est, uti majori anni circulo mediastini atque plebeii homines ex silvestribus fructibus, melle, herbisque laute victare possint....». Este passo de Damião de Góis vem transcrito na ob. cit. de Costa Lobo, p. 534. O texto é de 1541. Também Oliveira Marques, em A sociedade medieval portuguesa (Lisboa, Sá da Costa, 2. ed., 1971), num precioso capítulo dedicado à alimentação (pp. 7-22), refere que «No campo, a situação era um pouco melhor para o povo miúdo [de que nos grandes centros, devido às crises cerealíferas, como diz atrás]. Havia sucedâneos para o pão: a castanha e a bolota, por exemplo» (p. 15). Na mesma página, informa que «a base da alimentação medieval, especial- 
nista produz estas afirmações num texto propagandístico quando, à face da Europa, pretendia exaltar o éden português. Já outro humanista, Nicolau Clenardo, mostra um espanto vizinho do escândalo, ao observar que a alimentação dos azemeis que o guiavam na jornada pelo Alentejo se compunha, essencialmente, de cebolas cruas.

É evidente que nem sempre o organismo resistia: «.... não morrem de fome o rei, nem o príncipe, mas o pobre que achegar não pode ao valor grande do trigo, quando é caro em preço» (1). E se não era a alta ou a escassez dos cereais, era o excesso de foragens que tornava miserável a condição de braceiro.

11. Mas se André se preocupa com o sumiço da burra não é só pela perda de um animal de carga, mas porque «s'ela não parecer / atás per noite fechada, / não temos hoje prazer; / que na festa sem comer / não há hi gaita temperada» (2). Temos pois que os pastores se desenfadavam com cantares e danças. Como vem a acontecer, em epílogo místico-popular: "Tocam os anjos seus instrumentos $e$ as Virtudes cantando e os pastores bailando, se vão: LAUS DEO", diz a rubrica (3). Supomos que tal recreio era não só um desenfado da iniciativa dos guardadores de gado (ou outros trabalhadores rurais), como até incentivado pelos patrões ou maiorais, neste sistema patriarcal que parece vigorar no «reflexo do real» que é a cena pastoril do auto. Porque mais se conseguiria com estes intervalos lúdicos do que com uma exigência aturada... (4).

mente quanto ao povo miúdo, residia nos cereais e no vinho". E noutro passo do mesmo capítulo (p. 11), são indicados os legumes (frescos e secos). A carne e o pescado não eram habituais nas mesas do povo.

(1) Consulta do Catellão a El-Rei D. Duarte, cit. por Costa LoBo, ob. cit., p. 535 , nt. 3 .

(2) Auto da Mofina Mendes, "Idem», vol. 1.0, p. 142.

(3) Idem. p. 162.

(4) Segundo o agostinho Marcos Antonio Camos, «el yr regateando el padre de familias con sus moços por cosas leves y menudencias mayor dano causa, molestia y poca utilidad porque más se alcança aliviandoles con algumas burlas a ratos de su trabajo...,» cit. de Noel Salomon, Recherches sur le thème du paysan dans les "comedia" de Lope de Vega, Bordéus, 1965, p. 771. O conselho de paternalismo vigilante de Frei Marcos é, aliás, inspirado em Columella. A contratação de vilãos para animarem, com as suas «modinhas» e bailados, os serões do paço («defronte do rei, de grandes senhores ou de convidados ilustres", escreve Oliveira Marques, 


\section{OS PRÍNCIPES REBELDES}

12. Parece evidente que o «intermezzo» político só tardiamente se incluíu num auto que (se aceitarmos a tese de Révah) tinha sido já apresentado em $1515(1)$. Dá-se conta do escândalo que, desde 1527, agitava o mundo cristão e mobilizava toda a "inteligência» europeia numa campanha de opinião, de diferentes sinais e tónicas. Mas toda ela, qualquer que fosse o campo escolhido, se centrava na grande questão de princípio: guerra justa - guerra injusta, o que implicava a determinação do agressor. Na polémica, evidenciavam-se figuras de grande envergadura, como Erasmo, Pietro Aretino, Garcilaso, e muitos outros. Defendiam-se e atacavam-se os chefes intervenientes nas guerras. Mellin de Saint-Gellais, já citado, compõe até um pequeno poema no qual, em registo satírico, as lutas pela posse da Itália são descritas como um jogo de cartas (jeu de prime), aplicando à situação política, à repartição de forças, às vantagens e fracassos dos contendores a terminologia do jogo. Também François Rabelais, na sua «guerre picrocholine» põe em causa a política agressiva de Carlos $\mathrm{V}$, de Luís Sforza e Fernando de Aragão (2). Tomás Morus, na sua Utopia, igualmente tomou posição na refrega, posição de sinal oposto à de Rabelais - et pour cause - pois para o humanista britânico o agressor é, evidentemente, Francisco I, com pretensões à hegemonia mundial.

ob. cit., p. 199) é suficientemente ilustrada pelos remates dos autos natalícios vicentinos. Escusado será acrescentar que se está já perante uma recuperação da festa popular, que, ao tornar-se espectáculo para os outros perde as suas virtualidades de contra-cultura.

(1) A inclusão de um episódio como o da Mofina é possível nessa data, mas não teria o alcance que, em texto posterior, lhe damos. Porque, se as lutas pela hegemonia europeia entre Carlos V e Francisco I não se tinham ainda processado, também a acuidade da questão dos prognósticos era inexistente, e, portanto, a estrutura do auto, tal como a vimos no texto que nos chegou, era muito diferente.

(2) Pode objectar-se que a guerra «picrocholine» visa um mundo imediato (ou um micromundo) - pondo em causa o "pays du Loire»: os conflitos entre a família Rabelais, e aliados, e Gaucher de Sainte-Marthe, senhor de Lemé, proprietário das pescarias do Loire. A este sentido imediato sobrepõe-se, contudo, um sentido mais vasto: estaria em causa um conflito europeu. Picrochole seria assim (também) Carlos V (e, parcialmente, os agressores secundários, como Sforza ou o Condestável de Bourbon). Ver, a este propósito, a análise de Michaīl Bakhtine, em L'auvre de François Rabelais et la culture populaire au Moyen Age et sous la Renaissance, Paris, Gallimard, 1970, pp. 433-444. 
No satírico gaulês, o fenómeno histórico fixa-se em formas carnavalescas, próprias da "festa», no seu sentido específico de riso popular. Em Morus, a projecção na utopia é o processo escolhido. Ambos, porém, se ocupam e preocupam com este abalo profundo que faz tremer o mundo e seus alicerces. Não se trata precisamente de uma tomada de posição num plano filosófico, mas de toda uma mentalidade, de que eles são qualificados porta-vozes, e que tenta aperceber o mundo em tons novos. Curioso é notar que Rabelais faz uma aproximação entre cataclismos políticos e sociais e fenómenos cósmicos (inundações e tremores de terra), mas não para extrair desse paralelismo uma visão catastrófica. Pelo contrário, no mundo horizontal de Rabelais, à tempestade seguir-se-á a bonança.

13. Gil Vicente adopta, perante esta problemática, uma atitude de relutância na aceitação de um novo mundo que vê em termos de subversão hierárquica e de abandono dos moldes do viver patriarcal e cristão. As mudanças teriam de processar-se no plano do aperfeiçoamento individual. Esta proposta reformista - alternativa que o não é, pois enferma de um passadismo, no campo social, que se traduz na conformidade a padrões alienantes - torna-se mais evidente com o episódio da Mofina Mendes.

\section{MOFINA OU A ALEGORIA DA SUBVERSÃO}

14. A Mofina, como alegoria, encarna os três temas que já indicámos: a inversão hierárquica (rebelião dos príncipes cristãos contra o Papa; alianças «contra natura» com os inimigos da Fé); a emancipação do campesinato (faceta do mesmo fenómeno de subversão); a invasão da esfera de Deus - o futuro - através de um projecto emancipatório. Representa, por conseguinte, parte e todo da arquitectura do texto.

15. Desmontemos a apresentação da Mofina, da responsabilidade do maioral Paio Vaz. Em resposta à pergunta de André - «Mofina Mendes, quanto há, / que vos serve de pastora?» - declara: «Bem trinta anos haverá, / ou creio que os faz agora....».

Gil Vicente não avança uma data à toa: segundo o seu ponto de vista, a má sorte andava em Portugal há mais ou menos trinta anos. 
Já no Triunfo do Inverno (1529), se datava de há vinte anos a tristeza na nossa terra (1). Portanto, e sem rigorismos excessivos, a tristeza e a má sorte começam a afirmar-se na primeira década do século XVI, conotadas com a expansão no Oriente e a recessão no Norte de África. Em 1508 tentara-se, sem êxito, a conquista de Azamor, tomada mais tarde, é certo, mas com a mobilização de 15 mil homens. Quando se representa o Triunfo do Inverno, a situação em Marrocos está num ponto crítico: as guarnições dos castelos que aí possuíamos estão em permanente estado de alerta. Só à força de reforços humanos e de armas, com muita despeza, se conseguia manter uma presença, em breve quase só simbólica. Já conselheiros propunham o abandono de três praças: Ceuta, Argila e Tanger. Em 1533-34, a situação agravou-se, com o cerco de Safim, e, nos anos seguintes, outras praças vão sendo abandonadas. É para este doloroso panorama (que Gil Vicente sente como o ruir de um império cristão, baluarte contra o infiel) que a alegoria aponta.

Mas não só. Os estragos da Mofina não nos são específicos: ela lá vai, mensageira da desgraça, semear a cizânia entre os príncipes cristãos que deviam estar unidos: «.... Ela deu o saco em Roma, / e prendeu El-Rei de França: / agora anda com Mafona, / e pôs o turco em balança....». Ora com uns, ora com outros, ei-la que regressa ao nosso país, perturbando os pastores: destruindo a ordem estabelecida. Mofina em terra de cristãos (1), surge em cena para prestar contas dos seus serviços.

(1) «O Autor: Em Portugal vi eu já / em cada casa pandeiro, / e gaita em cada palheiro; / e de vinte anos a cá / não há hi gaita nem gaiteiro. / A cada porta um terreiro, / cada aldeia dez folias, / cada casa atabaqueiro; / e agora Jeremias / é nosso tamborileiro. // Só em Barquerena havia / tambor em cada moinho, / e no mais triste ratinho / s'enxergava uma alegria / que agora não tem caminho. / Se olhardes as cantigas / do prazer acostumado, / todas tem som lamentado, / carregado de fadigas, / longe do tempo passado. // $\mathrm{O}$ d'então era cantar / e bailar como há-de ser, / o cantar para folgar, / o bailar por prazer: / que agora é mau d'achar....».

(1) A expressão fomos buscá-la às notas críticas que o conde de Tentúgal, D. Francisco de Melo, redigiu sobre a Crónica do Felicíssimo Rei D. Manuel, da autoria de Damião de Góis. O cronista, no capítulo 9, punha em contraste a boa sorte de D. João-príncipe e a má sorte de D. João-rei. O censor escreve: «Acerca d'El-rei D. João se mostra quão suspeito é em suas coisas, usando de artifício retórico, e trata dele ser ditoso em príncipe e mofino em rei: os teólogos vejam se lhe dão licença para tratar de dita e mofina em terra de cristãos». (Vid. a transcrição feita por DAVID 
16. Paio Vaz, seu patrão, interroga a pegureira sobre o paradeiro da boiada. A resposta (a primeira fala de Mofina) é: «mas que cuidado vós tendes/de me pagar a soldada/que há tanto que me retendes!». O contra-ataque da assalariada traduz uma acusação concreta: há ordenados em atrazo. Paio Vaz não levanta a luva e prossegue uma inquirição que se revela infrutífera, porque Mofina só lhe apresenta um rol de mortandades, concluindo: «Meu amo, já tenho dada / a conta do vosso gado / muito bem, com bom recado; / pagai-me minha soldada, / como tendes concertado».

A leitura que se tem feito desta cena põe a acentuação no cinismo da «má pastora» que não olhou pelo rebanho e tem ainda a desfaçatez de exigir a sua paga. Numa palavra, só se vê na Mofina a alegoria da insensatez, quando ela é, além disso, a alegoria da subversão social e também, numa projecção do real, o símbolo do assalariado mal pago.

17. Os nossos historiadores medievalistas não deixam de registar a elevação das tabelas salariais no campo, a partir dos finais de Trezentos, e a consequência que daí advinha para o patronato rural em satisfazer o pagamento do trabalho prestado pelos seus jornaleiros. O próprio Gil Vicente reproduz, num outro dos seus autos, o Auto da $F e ́$, uma canção que poderíamos apelidar de protesto, embora, aparentemente, o artista a transcreva só para lhe explorar os efeitos folclóricos. É como uma litania, monótona na sua forma, dramática no seu grito: «No, no, no, no, no, no, / no, no, no, / que no, que no, / que no quiero estar en casa, / no me pagan mi soldada, / no, no, no, que no, que no. / No me pagan mi soldada, / no tengo sayo ni saya, / no, no, no, que no, que no» (1). Era uma canção popular do século XVI; é um documento social do século XVI.

LoPes, Prefácio à Crónica do Felicissimo Rei D. Manuel, de Damião de Góis, Coimbra, 1949, p. te I, p. XX). O defensor dos Braganças considera (e, com ele, estaria a opinião oficial) que mofina e dita, (sorte, fado, destino) seriam termos (conceitos) infiéis, que traduziriam um espírito fatalista, pouco ortodoxo. Tentados por esta pista, seríamos levados a dizer que Mofina Mendes é a mofina em terra de cristãos que a teologia (ortodoxia cristã) não poderia aceitar entre os seus.

(1) Auto da Fé, in «Idem», vol. 1..$^{\circ}$, pp. 95-96. A canção é entoada por Benito, um dos «dous pastores simpres» que, com Brás, são catequizados pela Fé. Cumpre dizer que a «simpreza» dos pastores (que hoje denominaríamos imbecilidade) não lhes dá acesso à compreensão da mensagem dessa Virtude. Portanto, a Fé, aban- 
$\mathrm{Na}$ vizinha Espanha, um pouco mais tarde, autores como Lope de Rueda põem na boca dos seus pastores declarações que não assumem também sequer uma leve tónica reivindicativa, mas tão só uma constatação de facto. É a espera de salário como situação habitual, em casa de infanções como na de maiorais - o que, como se sabe, se tornará passível de uma sátira constante (atingindo mesmo o estereotipo) na literatura portuguesa de Seiscentos e Setecentos. O maioral peninsular do século XVI é assim definido por Noel Salomon: «Patrão vigilante e zelozo dos seus bens, o nosso patriarca não se deixa ludibriar pelos pastores que lhe roubam as ovelhas: se necessário, retém-lhes do soldo o preço dos animais que eles declaram, falsamente, ter extraviado; se algum deles se mostra exageradamente desonesto, ele ameaça-o com o seu cajado» [os itálicos são nossos] (1).

Voltando à Mofina e à sua "conta de negregura». Segundo Costa Lobo, o Portugal dos séculos XV-XVI era ainda uma "brenha selvática» onde as alcateias de lobos eram tão numerosas que «até nas costas do mar os conselhos se viam obrigados a fazer-lhes montaria todos os sábados» (2). Acrescente-se a isto a falta de cobertos ou currais, para defender o gado das intempéries e das investidas dos animais ferozes, e ter-se-á uma ideia das condições não muito favoráveis para a manutenção de um rebanho. Além de que, fiando-nos no processo de prestação de contas (que é da responsabilidade de mestre Gil), a Mofina

donando a sua pedagogia, convida-os a cantar «per vosso uso acostumado / como lá cantais co'o gado". Este auto é uma nítida concessão a um público de Corte que se enterneceria com aquelas crianças grandes, tão felizes na sua santa ignorância.

(1) Noel Salomon, ob. cit., p. 765 . Na p. 764 , nt. 45 , o autor transcreve um passo da comédia de Lope de Rueda, El mejor alcalde d'el Rey que vem a propósito referir. Um jovem pastor, ao serviço do infanção $D$. Tello, declara: «.... y en este oficio / que os he dicho, cosa es clara / que no me coneceréis, / porque los criados pasan / de ciento y treinta personas, / que vuestra ración aguardan / y vuestro salario esperan». Trata-se, evidentemente, de uma grande casa, cujo pessoal atinge um número de membros desproporcional às posses do patrão. $\mathrm{O}$ problema era análogo para o pequeno e médio proprietário, pelos condicionalismos económicos e sociais. Entre estes últimos, convém não desprezar o fetichismo do prestígio: o número de assalariados era tanto maior quanto maior era o estatuto social a que o proprietário aspirava, ou se atribuía. Em Paio Vaz não é este o factor determinante, mas um outro: o querer criar grandes rebanhos com pouco pessoal e pouco gasto. Situamo-lo num estrato ascencional.

(2) Vid. Costa Lово, ob. cit., p. 82. 
tinha à sua carga um número excessivo de cabeças de gado, o que nos coloca perante outro problema: a escassez de mão de obra rural.

18. Embusteira ou desleixada, ou ambas as coisas, a pegureira recebe do amo um pote de azeite, paga à primeira vista generosa, mas não tão valiosa quanto parece, dado que o nosso país, nesse tempo, se encontrava coberto de extensos olivais, pelo que o azeite era um produto agrícola de escasso valor. Todavia, Mofina Mendes embarca num sonho, ao qual Gil Vicente empresta cores manifestamente carregadas. Mesmo sem se entrar em estudos aprofundados sobre o valor da moeda e o poder de compra, lembramos um pormenor de outro auto vicentino: quando o marido de Constança (Auto da India) refere à mulher a possibilidade de ter regressado rico, cita a quantia de um milhão de cruzados. Mofina, na venda hipotética do pote de azeite, chega ao milhão e meio. Até o traje de casamento que idealiza - o brial de escarlata - a classifica como criatura desprovida do sentido dos limites: a escarlata era o tecido principesco por excelência, e o brial tinha já, aliás, caído em desuso. Porém, o desatino (infracção às pragmáticas) não atingia só esta Mofina, mas outra «gente mean e meúda", pois "até os de baixa sorte vestem panos de seda e de fina lã, como outrora os fidalgos usavam» (1). Como se sabe, a presumível noiva não chega a envergar o brial porque o pote cai e ela não atinge o "pays de Cocagne» (2): todo o humano deleite há-de dar consigo em terra. A pastora fracassa na sua dupla aspiração: passar de assalariada

(1) Cfr. Costa LoBo, ob. cit., pp. 399-400, onde refere passos da representação às Cortes de 1481 e 1482 . Saliente-se, todavia, que a pastora, se peca por excesso ao visionar um traje despropositado para o seu actual estatuto, insere-se numa lógica social que baseia a consideração devida ao indivíduo nos sinais externos. Em Portugal, na época, os mesteirais, pelas pragmáticas vigentes, distinguiam-se, aliás, dos trabalhadores rurais. Estes só podiam usar panos de lã mais grosseira: aos primeiros era permitido o uso de tecidos de lã de meia fineza. Ver, também o capítulo interessante e documentado que o Prof. Oliveira Marques dedica ao traje, na obra já citada.

(2) Para nós, Mofina, ao aspirar a uma vida materialmente próspera - uma abundância possível - embarca para o «pays de Cocagne». Não é a utopia, centrípeta e ascética, mas um lugar (ou um não-lugar, pois é sonho compensatório), em que o trabalho já não existe. É a fuga às contingências servis, às frustrações alimentares. Na sua forma acabada, é o país dos glutões e dos ociosos: o Schlaraffenland. 
a regateira e de solteira a desposada (1). Todavia, sai cantando, segundo a rubrica, como se o autor não a pudesse impedir de ir construir o seu sonho algures.

19. Esta leitura privilegiou os dados sociológicos, dela se extraindo uma lição moralizadora a dois níveis. Num deles, avulta o Gil Vicente "fazedor de autos d'El-Rey». Funcionário palaciano durante 34 anos consecutivos, o artista acabou por assumir valores e interesses de uma das camadas sociais das classes hegemónicas (2). Em Portugal, na época, existiam nos estratos superiores, duas correntes que se afrontavam numa luta surda de manobras de bastidores, com vista ao domínio do aparelho de estado. Uma é a velha aristocracia, a nobreza cavaleiresca, à qual interessava a fixação no Norte de África. É uma nobreza agrária, imobilista e conservadora. A outra é a nobreza secundária, aquela cuja base social e económica de apoio é o mundo mercantilista, é a expansão no Oriente.

Dois fenómenos se estão a processar - como já se referiu - que, em planos diferentes convergem para o mesmo fim: o abandono das praças do Norte de África e o êxodo dos trabalhadores rurais para a cidade. A nobreza de Gil Vicente - a dos feitos de África: da Exortação da Guerra e dos cavaleiros da Barca do Inferno - se ainda conservava esperanças de hegemonia, vai-as perdendo com o fim do reinado de D. Manuel. No dealbar dos anos 30, tornara-se manifesto

(1) As pastoras, por motivo de uma vida mais livre - vinda de noite para casa, ou até pernoita nos cobertos, e consequente promiscuidade - tinham mais dificuldade em encontrar noivo compreensivo. Em ritos nupciais, usados ainda no século XIX em certas regiões serranas, a família da pastora, representada pelo pai ou, na falta deste, por irmão ou outro parente do sexo masculino, entregava-a ao noivo com uma advertência cautelar: «Ela cabras guardou. / Sebes saltou; / se em alguma se espetou, / e a quereis, / assim como é,/assim vo-la dou». F. FalCão Machado, $O$ "Gadensteignen» em Portugal in "Feira da Ladra», vol. 8..$^{\circ}$, p. 73.

(2) A este fenómeno de colagem, geralmente denominado de solidariedade vertical (expressão que nada explica e só rotula), e que se traduz por uma adaptação aos padrões de um grupo de referência, admirado e cortejado, chamam os sociólogos funcionalistas «anticipatory socialization». Trata-se de um fenómeno tão digno de atenção (por não menos determinante) como a luta de classes para a compreensão do processo histórico. O sujeito, quer individual quer colectivo, ao deixar-se fascinar pelo prestígio de um grupo-modelo, não o faz gratuita e especulativamente. A atracção desse grupo repousa no poder político e nos privilégios económicos de que usufrui e que o convertem em alvo a atingir pelas camadas sociais em trânsito. 
que a manutenção das praças africanas era insustentável. Por outro lado, a fuga dos trabalhadores rurais para os meios urbanos ${ }^{(1)}$, ou mesmo para além-mar, afectava uma lavoura deficitária, em fase de reconversão das terras baldias em terrenos de cultivo. Estes dois factores conjugados perturbaram todo o equilíbrio económico, político e social da aristocracia agrária. Mas, nesta defesa manifesta que o dramaturgo faz da permanência de uma certa estrutura, na qual a agricultura e a pastorícia gozam de uma preponderância sobre as outras actividades económicas, o que acarreta a estabilidade das relações de produção (com a continuação dos laços de dependência entre senhores e servidores), as contradições não the passam despercebidas. Para o homem cristão que é Gil Vicente, o mau patrão tem de ser admoestado. Daí os casos exemplares do lavrador que geme na Barca do Purgatório e na Romagem de Agravados - posição que nada tem de contestatária (no sentido revolucionário do termo), mas se insere num reformismo de cariz paternalista.

Também não era alheio a este estado de espírito - senão de alarme, pelo menos de alerta - o que na Europa, e mesmo na vizinha Espanha, se estava a passar ao nível do campesinato. Em fins do século XV, a Catalunha e a ilha Maiorca assistem às primeiras revoltas, em grande, dos rurais. Mas é sobretudo a partir de 1524 que, na Alemanha, se processam os grandes levantamentos dos camponeses - contra os quais Lutero, em 1525, lança o seu anátema.

Que estes movimentos tinham impacto entre nós, prova-o o facto de um repórter dos «mirabilia», como Garcia de Resende, se fazer eco dos acontecimentos, na sua Miscelânea: "Os povos de Alemanha / vimos todos levantados, / contra os grandes adjuntados, / e entre eles guerra estranha;/os grandes desbaratados, / os fidalgos não ousarem / de parecer, nem falarem, / os vilãos victoriosos, / soberbos, e poderosos, / em busca deles andarem»(2).

(1) «.... leis e posturas foram impotentes para obviar à transferência, do campo para a cidade, de grande parte da população rural. Os criados fugiam aos amos ou preferiam assoldar-se à semana ou ao mês (em vez de ao ano, como mandava a tradição) para maior liberdade de movimentos» (Oliveira Marques, ob. cit., p. 136). A citação aplica-se aos finais do século XIV e $1 .^{\mathrm{a}}$ metade do século XV, mas a situação agravou-se durante o século seguinte.

(2) Miscelânea, cit., p. 371. 
20. Se Gil Vicente, no Auto da Mofina Mendes, se ergue contra toda a tentativa de subversão, contra tudo o que possa pôr em causa a ordem e a hierarquia - os valores tradicionais -, essa posição não se enraiza apenas na sua inserção social, mas também na sua vivência cristã. .

Como cristão, situa-se na corrente denominada da Restauração Católica, corrente essa que desabrocha na Europa durante o cisma do Ocidente. É uma corrente de bases, de militantes, sem cobertura, a princípio, da hierarquia eclesiástica; mais ou menos combatida por esta, tem a sua primeira afirmação no Concílio de Constança (1412), através do chanceler Gerson e de Nicolau de Clemanges, formalizando-se depois no Concílio de Basileia (1432-1438). Este movimento foi, durante a maior parte do século XV, visto, como se disse, com maus olhos pela hierarquia eclesiástica, por variados motivos, entre os quais avulta o conflito em que o Concílio de Basileia se envolveu com o Papa Eugénio IV. Apesar disso, foi ganhando sempre maior influência dentro da Igreja e acabou por ter uma certa oficialização no $5^{\circ}$ Concílio de Latrão (1513-1517). Este movimento pretendia o congelamento das especulaçð̃es teológico-filosóficas e o voltar do apostolado cristão para a vida cristã. Daí a crítica ao intelectualismo escolástico e aos seus representantes, preconizando o regresso às origens do cristianismo e a reconversão das congregações religiosas ao espírito da época da sua fundação.

Mas este sobressalto evangélico, que tão evoluído foi, já nesta época não respondia aos problemas e às implicações dos homens de uma economia com tendência para se tornar de mercado. Estes, inseridos em corporações ou em associações urbanas, empenhavam-se numa comunidade horizontal que, através da iniciativa e da livre opção, conduzisse a uma autêntica tomada de consciência. A este anseio vem responder um erasmismo, vem responder um humanismo cristão. E, todavia, na devotio moderna, estava já, em gestação, a nova moral.

21. Na 2. a cena do auto que temos vindo a analisar (ou 1.a , se considerarmos a fala do frade como introdução), o relevo dado por Gil Vicente à virtude da prudência insere-se numa linha de pensamento que revolucionou toda a apreciação do acto humano.

Evoquemos a cena. A Virgem surge «vestida como rainha», acompanhada pelas suas quatro criadas e quatro anjos músicos. Neste quadro de vida senhorial, dama Prudência, uma das aias, vai ter des- 
taque significativo. As suas intervenções ocupam 34 versos, repartidos por 7 falas; segue-se a Fé, num total de 25 versos, distribuídos por 4 intervenções. Considerando a cena dividida em duas partes - antes da vinda do anjo Gabriel e após a sua chegada - verifica-se que, no $1 .^{\circ}$ momento, Prudência leva vantagem, ao passo que, no $2 .^{\circ}$ momento, está quase equiparada à Fé. A leitura parece ser: na deliberação a tomar pela criatura, a prudência terá o papel primordial; na fase de realização do acto, fé e prudência devem andar de mãos dadas (1).

22. O Auto de Mofina Mendes não terminou com a saída do palco da pegureira, como não se iniciou com a sua chegada. Tem-se feito, aliás, notar a alternância do sagrado e do profano, numa dialéctica bem conseguida, neste texto vicentino (2). A dialéctica Luz-Trevas que pode ser glosada quase indefinidamente: Verdade-Erro; Sabedoria divina-Ignorância humana; Prudência-Insensatez....

Os pastores ficam em silêncio e, em breve, adormecem, num sono de que o anjo os vem despertar para que vejam a Boa Nova: para que participem na festa da Luz que vem iluminar este mundo - a noite

(1) «En vérité, voix de la conscience et vertu de la prudence sont étroitement coordonnées, à ce point que l'accent mis sur l'une ou sur l'autre de ces ressources introduit deux conceptions différentes de la morale: les modernes casuistes chrétiens ou philosophes rationalistes exaltent la conscience: la théologie de Saint Thomas situe l'éducation de la conscience dans l'exercice de la prudence.... Ce que nous avons à souligner pour notre propos, c'est la suprême valeur d'une vertu qui a pour fonction spécifique d'incarner dans l'action singulière hic et nunc les principes de la loi éternelle: conjunction de la sagesse et de l'invention toujours neuve, conjunction de l'objectivité avec la plus intérieure subjectivité. Dans une sculpture d'une étonnante audace, au tombeau du dernier duc de Bretagne, à Nantes, Michel Colombe (1502-1507), réprésenta la Prudence, selon la tradition iconographique du Moyen Âge, dans un personnage à deux visages, l'un celui d'un homme d'âge mur, pénétré de refléxion, l'autre celui d'une jeune femme, ouverte aux audaces. Parfaite image d'une vertu qui inscrit l'érernel dans le temps, là où les conjonctures imposent, au plus secret des décisions, une invention permanente. Sans doute est-ce là, dans la pensée médiévale, la plus belle pièce de son analyse de l'acte humain» (M. D. CHENU, L'évéil de la conscience dans la civilisation médiévale, conférences Albert-le-Grand, Paris, 1969, pp. 57-58). Esta longa citação, tão rica de virtualidades para a compreensão da moral de intenção e do primado da consciência, na linha das posições de Abelardo e do socratismo cristão, dispensa comentários.

(2) Vid. Dias de MAGalhães, $O$ significado do auto vicentino da Mofina Mendes, in «Brotéria», vol. 39, fasc. 2-3 e 4, Lisboa, 1944. 
escura. Portanto, temos os pastores dignos de ver a Luz e os pastores indignos (a Mofina) que são expulsos para as trevas exteriores, privados do acesso à Revelação.

Numa leitura final, parece-nos de interesse pôr em destaque a estrutura em que se insere (a nosso ver) o auto; a fábula da Mofina, como matéria mítica e suporte simbólico.

MITO E SIMBOLISMO NA MOFINA MENDES

23. Os estudos de Dumézil sobre o vocabulário religioso dos povos indo-europeus, centrados numa análise ideológica, levaram-no a deter-se sobre o alcance cultural da tríada latina: Júpiter-Marte-Quirinus (1).

Cada deus tinha o seu domínio de intervenção: Júpiter - a soberania jurídica e mágica; Marte - a coragem e a violência; Quirinus - a fecundidade e a paz. Em nova etapa de trabalho, Dumézil dissocia esta estrutura do sagrado e aplica-a ao plano social - sacerdotes, guerreiros, agricultores (ou ganadeiros) - que lhe estava ligado necessariamente. Aplicando à produção simbólica esta estrutura recorrente, verifica-se a sua existência, mesmo larvar, nas narrativas populares (segundo Lévi-Strauss, os contos populares são mitos atenuados - affaiblis), e, evidentemente, na epopeia e no romance.

E não é raro que estes mitos se carreguem de um sentido histórico particular, passando a significar, por exemplo, as lutas pela apropriação do poder. Fenómeno que nada tem de insólito, se nos lembrarmos que, como o rito nas nossas sociedades, também a matéria mítica se presta a diversos reinvestimentos semânticos.

Postas estas considerações de base, vejamos como a estrutura tri-funcional serve de suporte ao auto vicentino que nos tem servido de padrão. Recorrendo ao quadro elaborado por J. C. Rivière (2), temos:

Primeira função - Deus principal: Júpiter; Funções: Soberania jurídico-política e «mágica»; Ideias associadas: o saber e tudo o que

(1) G. DumÉzIL, Rituels indo-européens à Rome, Paris, Klincksieck, 1954: Mythe et épopée, I, II, III, Paris, Gallimard, 1968-1973: Du mythe au roman. La saga de Hadingus, Paris, PUF, 1970; Romans de Scythie et d'alentour, Paris, Payot, 1978.

(2) Ver Daniel Fabre, Mythe in «La nouvelle histoire» (dirigida por Jacques Le Goff), Paris, Retz, 1978, pp. 430-437, onde é reproduzido o quadro tri-funcional de J.-C. Rivière, extraído do seu trabalho Pour une lecture de Dumézil («Nouvelle École», n.os 21-22, 1972-1973). 
respeita à política, ao direito, ao religioso, ao sagrado; Grupos sociais: Reis, Padres - Oratores; Qualidades principais: Sabedoria; Pecados capitais: Juramento traído, abuso do poder, incantação maléfica.

Segunda função - Deus principal: Marte; Funções: Força física: Ideias associadas: Uso (pacífico ou guerreiro) da força física; Grupos sociais: Guerreiros, nobreza - Bellatores; Qualidades principais: Bravura; Pecados capitais: Cobardia, abuso do poder, recurso excessivo à força.

Terceira Função: Deus principal: Quirinus; Funções: Fecundidade, juventude, saúde; Ideias associadas: Riqueza, abundância de bens, gado, colheitas; Grupos sociais: Pastores, criadores de gado, agricultores-Laboratores; Qualidades principais: Temperança; Pecados capitais: Roubo, intemperança.

Aplicando ao auto este esquema funcional, verifica-se que a sua estrutura se lhe adapta perfeitamente. No prólogo, o frade-sandeu põe em causa o clero (ORATORES) que detendo a sabedoria (qualidade principal) por inerência das funções de que está investido (soberania no campo do sagrado), incorre no abuso do poder (pecado capital), prognosticando e não profetizando - o que só poderia fazer avalizado pela inspiração divina.

Os bellatores - Carlos V e Francisco I - pelo abuso do poder (que se confunde aqui com o recurso excessivo à força) invertem os dons de que estão revestidos: a bravura torna-se cobardia.

Os LABORATORES - designação que engloba os pastores - são representados por dois tipos antitéticos: o bom e o mau pastor. $\mathrm{O}$ bom pastor (André e companheiros e também o maioral Paio Vaz) possui a temperança - o sentido dos limites - e cumpre a sua função social: produzir riqueza. O mau pastor (Mofina Mendes) inverte a qualidade própria: roubando (sentido directo de furto ou indirecto de prejuízo aos bens de outrem) e incorre no pecado da intemperança pelo olvídio do sentido das limitações.

As três funçðes estão distribuídas por três grupos, mas só um deles é ilustrado em dois planos: positivo e negativo. De onde poderíamos ser tentados a uma leitura: só no mundo rural haverá virtualidades que conduzam a um equilíbrio - aí, há bons pastores. A subversão não atingiu todos. Corrigidos certos desvios, nessa inocência e simplicidade está o mundo a reencontrar. Porque - note-se-Gil Vicente não apresenta o bom clero (o frade sandeu é mais sandeu que 
frade: é bufão, que denuncia porque afivelou a máscara desculpabilizadora); não apresenta o bom príncipe cristão: censura à não-beligerância nacional na guerra contra o Turco?(1)

24. Mas também - neste jogo de espelhos que é o mundo do imaginário - podemos considerar a Mofina, a má pastora, parte e todo. Porque ela incarna a completa subversão: ela antecipa o futuro (invadindo a esfera mágico-sagrada) no seu sonho de promoção; é-lhe assacado o espírito de violência e loucura que anima os príncipes cristãos («intermezzo» político, pela boca de Paio Vaz); ela atenta contra a paz e a fecundidade, pois a pastorícia é imagem de harmonia e ela traz a perturbação. De onde se poderia partir para outra lição: na inversão hierárquica que se chama emancipação do elemento rural, reside o pecado original: a causa de todo o desequilíbrio. Toda alteração de um elemento se repercute na arquitectura do conjunto. Ou, noutra redacção: as veleidades emancipatórias do campesinato são consequência da degradação do poder, da demissão dos «notáveis» - clero e nobreza.

Ou ainda, num processo redutivo extremista, desviada a autoridade religiosa da sua verdadeira finalidade, não sofrem as outras funçð̃es alterações em cadeia? Isto é, se o clero se arroga o direito de utilizar, manipulando-a, a ciência (inclusive para fins sectários) (2), como estranhar que a coragem seja investida (invertida) em actos de violência, de onde resulta uma alteração da sociedade - onde deve reinar Quirinus (a fecundidade e a paz) e onde se instala a esterilidade (a deserção dos campos)?

25. Não nos iremos deter na linha genealógica da fábula em que assenta o episódio de Mofina Mendes. Qualquer enciclopédia regista

(1) Até 1532 (campanha da Áustria), a guerra contra o infiel só era entendida, na Península, em termos norte-africanos. A partir de então, a questão turca, considerada europeia mas não nacional, é encarada como problema de toda a Cristandade. Torna-se a mola de arranque que leva os peninsulares a abandonarem uma visão medieval e a adoptarem (embora transitoriamente) uma visão universal. Ver, em ligação com esta problemática, o trabalho de ALberT MAS, Les réactions des espagnols face au péril turc durant la première moitié du $X V I^{\mathrm{e}}$ siècle, comunicação ao XI. ${ }^{\circ}$ Congresso nacional da «Société des Hispanisées Français....», Universidade de Lião, 1975.

(2) Cfr. Sermão de Santarém, já referido. 
o trajecto, seus entroncamentos, desvios e chegadas, ou não, no horário (histórico) previsto (1).

$\mathrm{Na}$ descodificação das fábulas, há que partir em busca dos símbolos, tendo em vista que um vocabulário do simbólico, acessível ao público de um determinado espaço e tempo, poderá hoje não ser apreensível. Tentaremos destacar, e apreender, o simbolismo, não só dos elementos (agentes ou acidentes) da fábula propriamente dita, como dos dois núcleos significativos que precedem e sucedem à fábula.

O núcleo significativo antecedente à apresentação da fábula é dominado pelo simbolismo do pastor. Impõe-se uma visão prospectivo-simbólica do termo.

Na tradição judeo-cristã, o pastor (de Israel, e, por extensão, da humanidade) é Deus. Também é pastor o delegado (chefe temporal e religioso) de Deus e os chefes humanos (executantes dos autênticos pastores: os anjos). O Novo Pastor é o Messias que «faz pastar o rebanho do Senhor na fé e na justiça» (SIR, 17, 45). Dentro de um simbolismo já especificamente cristão (Novo Testamento), Cristo é o bom pastor (João, 10, 11 ss.) e não um mercenário, mas aquele que está pronto a dar a vida pelas suas ovelhas.

$\mathrm{Na}$ cena que antecede a entrada de Mofina, estão presentes, mesmo só por referência, os pastores por inerência de cargo: o Papa e os príncipes: os ungidos. $\mathrm{E}$ aqui encontramos, de novo, os maus pastores que, como Saúl - o eleito - são rejeitados. Recebem o castigo pelo derramamento de azeite (a unção): saque de Roma (o Papa); prisão (Francisco I); derrotas sucessivas (Carlos V). No plano do imaginário, existe uma prefiguração da cena da Mofina.

$\mathrm{Na}$ fábula da Mofina, propriamente dita, o simbólico repousa nos mesmos elementos - pastor e azeite (2). Mofina Mendes não encarna o autêntico pastor: não dá a vida pelas suas ovelhas, porque

(1) A notícia mais correcta, a nosso ver, ainda é a registada, sob a rubrica Perrette et le pot au lait, no Larousse do século XIX (Grand Dictionnaire Universel $d u X I X^{\mathrm{e}}$ siècle, t. $12 .^{\circ}$, Paris, 1874, p. 652 , cols. 2 e 3).

(2) O episódio do derramamento de líquido na versão francesa desta fábula - Perrette et le pot au lait - tem sido explorado num sentido erótico, em leituras psicanalíticas recentes. $O$ facto de a nossa Mofina andar dançando, numa espécie de rito nupcial, torna talvez essa pista sugestiva. Sobre o episódio de Perrette ver as referências feitas por AlAIN GUILleRM, Le système de l'iconographie galante, in «Dix-Huitième Siècle», n. ${ }^{\circ} 12,1980$, pp. 177-94. 
é mercenária. $\mathrm{O}$ azeite é símbolo da prosperidade (que a mentalidade hebraica não distinguia do sinal da benção divina - Deuteronómio, 33, 24); da alegria (Salmos, 4, 5, 8), da fraternidade (Salmos, 133, 1-2). A pegureira perde a prosperidade: o seu único bem, e até talismã de acesso à promoção social; e a fraternidade: rejeita os seus pares e é por eles rejeitada. Perde a alegria? Gil Vicente fá-la sair cantando e esse registo - que parece insólito - é relevante para a leitura da ambiguidade da personagem que é (não se esqueça) também a alegoria da insensatez humana: a contra-prudência.

Segue-se a noite. Mas temos de separar a noite como símbolo de trevas eternas, de morte - para Mofina - e de noite preparação do dia - para os bons pastores, que aguardam a Luz. A noite é assim tempo de gestação ou de germinação (e não de decomposição). E o que germina acabará por brotar à luz do dia em manifestação de vida.

26. Esta leitura, apenas esquematicamente esboçada, aponta outra sobreposta ou complementar: a ritualística. O Auto de Mofina Mendes, ou dos Mistérios da Virgem, é um auto iniciático. Todas as etapas da admissão do profano até à assumpção ao Conhecimento estão presentes. $O$ frade-sandeu é o mundo profano, com os seus falsos valores, que o iniciando deve deixar para trás. A cena da Virgem, com as Virtudes, é já o templo - expõe-se aí a pedagogia de uma admissão a que o candidato aspira. Uns (bons pastores) conseguem passar as provas, que aqui são de cariz catecismal: têm a humildade, a pobreza, a fé e a prudência. Contentam-se com a sua condição, asseguram-se que o anjo não é um falso profeta e, tirada essa dúvida, creem na simplicidade do seu espírito.

Outros candidatos - a Mofina - não passam as provas: tiveram a oportunidade, mas desprezaram-na e, por isso, são condenados às trevas exteriores, enquanto os admitidos são conduzidos pelo «psychopompe» à Revelação. É a Morte e Ressurreição, subjacente a todo o ritual iniciático e presente em toda a liturgia cristã, como a natalícia e a pascal (1).

(1) A morte e ressurreição, mesmo através das vicissitudes de um personagem mítico, são uma das constantes de todo o ritual. Assim como: o duplo significado de certas acções - positivo e negativo, triste e alegre; e o recurso à figura do «farmakon", o que expulsa os males do grupo social. Atente-se também a que, no calen- 
Também o simbolismo das estações, presente nas representações do sagrado, se poderia aqui invocar: a renovação da natureza, o eterno retorno. Em Gil Vicente a predilecção pelos autos natalícios, se deriva das encomendas e dos costumes do paço, também se compreende à luz de uma marca ruralista. Além dos autos natalícios, incluindo o dos Reis Magos, outros há que, no título - Triunfo do Inverno, Auto das Quatro Estações - evocam uma ligação com a Natureza que, para além da lição cristã, evoca toda a herança pré-cristã das festas agrárias: das primícias, da primavera. E também o longo sono do mundo vegetal.

Sobre a visão vicentina da morte e sobre a proposta da vida, nos iremos agora debruçar.

A MORTE E A VIDA (1481-1557)

27. Em Gil Vicente, a morte ronda sempre, como personagem familiar. Metaforicamente, ela está presente na Mofina Mendes. Na Trilogia das Barcas e no Breve Sumário da História de Deus aparece sob forma alegórica; ritualizada, temo-la no Pranto à morte de D. Manuel e nas Orações dos Grandes de Portugal a Nossa Senhora, depois de enterrado El-Rey; manualizada, encontra-se no Sermão à Rainha D. Leonor. E oficializada, figura no epitáfio - Sepultura de Gil Vicente.

A ideia-mestra das Barcas consiste, numa transposição dinâmica da imagística das danças macabras, na igualização perante a morte: abolição de distinções de idade, classe ou privilégio. É a morte «redresseur des torts» - a morte que corrige injustiças (1). Todavia, trata-se do texto didáctico: é a nossa morte, a morte de todos, e nesta indeterminação de sujeito transparece uma familiariedade. As Barcas eram danças macabras em quadros vivos; uma espécie de reciclagem catecismática, que nada trazia de novo no capítulo do conceptual.

dário popular (arcaico), as festas natalícias pertenciam ao ciclo pré-carnavalesco: a renovação e a inversão eram motivos ritualísticos, permitindo a troca dos trajes próprios de cada sexo. Mofina Mendes, como personagem, incarna o «travesti», projecção visível e total da subversão.

(1) Esta leitura imediata não deve fazer perder da vista a outra face da moeda. A igualdade na morte pode servir de arma consoladora, se usada numa pedagogia do conformismo. 
Quando Gil Vicente presta homenagem ao seu rei - De Gil Vicente à morte do muyto alto e esclarecido rey Dom Manoel o primeyro do nome - fá-lo sobretudo para extrair desse passamento uma filosofia: a vida é vã, as grandezas de um dia são nada. Oferece-nos, por isso, mais um memento homo de que a celebração oficial do cortesão. Já as duas composições intituladas Romance e Orações dos Grandes de Portugal a N. Senhora, depois de enterrado El Rey possuem um interesse diferente. O Romance vai na linha dos prantos medievais, que, por sua vez, se inspiram nas ladaínhas fúnebres dos gregos (os epicédios). No Romance, merece destaque o quadro familiar - não só os parentes, mas os cortesãos - , com as intervenções das duas figuras femininas, a Infanta e a Raínha; e, acima de tudo, o registo da consciência que o Rei tinha da proximidade da morte: «.... O bom Rei em seu acordo / deste mundo se partia. / Sua morte conhecendo, / com muita sabedoria, / por palavras piedosas / os sacramentos pedia; / falando sempre com todos, / deu sua alma a quem devia» (1). Conhecimento esse que derivava da vulgarização das artes moriendi: o cristão sabia quais eram os sinais da morte. No Sermão à Rainha D. Leonor, Gil Vicente glosa, com minucioso realismo, nove sinais da morte. Longe de o tema parecer assustador, a morte era encarada com tanta naturalidade e confiança que não se acha descabido que tal composição seja apresentada a D. Manuel na noite do nascimento do Infante D. Luís. É certo que a corte se encontrava em Abrantes, fugida à peste, e o espectáculo da morte, ceifando vidas de parentes e amigos, era diário. Morte e nascimento (ressurreição), os dois polos da vida, estavam estreitamente associados. Até porque o número de mulheres que perdiam a vida ao dar à luz e de crianças que não ultrapassavam os primeiros anos era elevado (2).

(1) G. Vicente, Romance (à morte de D. Manuel), in «Idem», vol. 1. ${ }^{\circ}$, p. 205.

(2) É conhecido o extenso rol dos falecimentos de infantes crianças ou jovens e de princesas em parto, no tempo de D. João III. Não achamos descabido relembrá-lo. O 1..$^{\circ}$ filho de D. João III, o príncipe D. Afonso, morreu muito criança; a princesa D. Maria faleceu, aos 17 anos, em trabalho de parto. Duas infantas, D. Isabel e D. Beatriz, morreram ainda de berço, e um príncipe, D. Manuel, não chegou aos três anos. Também o príncipe $D$. Filipe e o infante $D$. Dinis não ultrapassaram os primeiros anos. Já o príncipe D. João, pai de D. Sebastião, atingiu a juventude, mas não passou do seu limiar, enquanto o infante $D$. António morreu muito menino. A imperatriz D. Isabel, irmã de D. João III, não resistiu ao parto de um nado-morto; o cardeal D. Afonso, irmão do Rei, morre aos 31 anos e, logo 
As Orações dos Grandes de Portugal podem aproximar-se das endeixas aos mortos, muito em uso na Península. A composição, pelo seu ritmo, evoca um desfile fúnebre, digno de um rei. Nesta homenagem prestada por Gil Vicente a D. Manuel, já ressalta o carácter externo, oficial, da morte. Porque, segundo Garcia de Resende, «vimos grão planto fazer/polos reis, quando morriam;/ burel, grande dó trazer, / .... e vimos pouco sentido / um rei que depois morreu....» (1).

Dos textos vicentinos até aqui citados, pode já depreender-se uma certa visão da morte: alguém que vem «de fóra», mas que se conhece bem e se tem de receber (influência do imaginário medieval); a chegada próxima é anunciada (os sinais são os batedores), dando tempo à preparação, quanto mais não seja a uma interiorização que resulta num colóquio entre a criatura e o Criador. Conhecendo o cristão os sinais, aproveita as suas faculdades, mesmo diminuídas, para tratar dos negócios do corpo - testamento, dádivas, recomendações - e dos da alma : sacramentos, participação na liturgia dos agonizantes, jaculatórias. $\mathrm{O}$ moribundo preside à própria morte, como actor principal do último acto. Pode captar-se o desenrolar do cerimonial da morte, nesta época, através do testemunho dos cronistas que narram os últimos momentos da vida dos grandes (2).

28. Remontemos a 1481, à morte do último rei cavaleiro, D. Afonso V: morte exemplar do herói que, enfim, descansa dos seus trabalhos. Mostra-se agradecido a Deus por «o deixar morrer em seus reinos, e em sua casa e sua cama, com conhecimento da sua morte» (3), o que lhe permite fazer o que «cumpria»: testamento, confissão, comunhão e extrema-unção. Está preparado para a viagem: abraça o filho - quadro de amor paternal-filial - e pacificamente

a seguir, o Infante D. Duarte. Estas últimas mortes ocorrem em fins de 1539, princípios de 1540. E logo em 1543, com apenas 22 anos, faleceu um outro infante D. Duarte, filho natural do Piedoso. Cfr. Francisco de Andrada, Crónica de D. João III, Porto, Lello e Irmão, 1976.

(1) Miscelânea cit., p. 374.

(2) Pode objectar-se que interessaria registar a morte dos outros homens. Simplesmente, no tempo a que nos reportamos, a morte com ficha do morto era só a de príncipes ou notáveis. Ou então, a morte em abstracto, aplicável a todo o ser mortal. A mesma conclusão chegou MárIo MARTINS na sua Introdução histórica à vidência do tempo e da morte (Braga, Livraria Cruz, 1969, 2 vols.), trabalho do maior interesse, embora numa perspectiva diferente daquela em que nos situamos.

(3) Garcia de Resende, Crónica de D. João II, ed. cit., p. 27. 
entrega a alma a Deus. Não interessa saber se o Africano morreu assim - e até é possível que fosse exactamente assim; porque, embora contasse apenas 49 anos, estava gasto física e moralmente.

A morte do filho e sucessor, D. João II, sai um tanto destes cânones, pois o assalta como ladrão de estrada: «.... faleceu el-rei sem pai, nem mãe, sem filho, nem filha, sem irmão, nem irmã, e ainda com muito poucos [acompanhantes], fora de Portugal, no reino do Algarve, em Alvor, muito pequeno lugar» (1). No entanto, apesar de viandante, o Príncipe Perfeito, depois de um breve momento de desânimo, prepara-se para a recepção da inevitável visita. Compenetrado do que lhe compete como sujeito de acto tão transcendente, dirige ele próprio os preparativos: manda armar um altar e, desfeita a cama alta em que jazia, ordena que lha façam. no chão. Só então dá início aos cuidados materiais e espirituais.

D. Afonso $\mathrm{V}$ é como que um príncipe da Távola Redonda; D. João II, como que um Rei Lear em busca de um filho (do amor do fim da vida). Têm ambos um idêntico desenlace: o do príncipe cristão que vai para o reino eterno. Porque se um foi o monarca medieval, quixotesco e aventureiro, e o outro o monarca de espírito moderno, o rei centralizador, ambos encararam a morte de frente. A mudança de atitude perante a morte é um fenómeno de «longa duração». A morte de D. João II evoca-nos, também, irresistivelmente, uma morte cavaleiresca: a de Roland (2). Este fica só, deitado no chão, aguardando a hora derradeira. Mas é igualmente um Rei Lear que, partindo em busca de «sua filha a meor» (de seu filho natural...), não a encontrasse e morresse ao desamparo (3).

D. Manuel, ao entrar na agonia, começou a recitar os salmos («de que sabia muitos de cór (4)») e, rodeado de prelados, religiosos e cortesãos, expirou. A morte do monarca obedeceu já a um cerimo-

(1) IDEM, ibid., p. 289.

(2) "Ço sent Rollant que la mort le trespend / Devers la teste sur le quer li descent, / Desuz un pin i est aler curant, / Sur l'erbe verte s'i est culcket adenz') ou, em francês actual: «Roland sent que la mort le pénètre / et lui descend de la tête au coeur; / il court sous un pin / et se couche sur l'herbe verte, face contre terre» (estrofe 174, da 2.8 p. ${ }^{\text {te }}$ da Chanson de Roland, vs. 1-4).

(3) Segundo Rui de Pina e Garcia de Resende, D. João II renunciou à presença do filho, na hora final.

(4) Damião De GoIs, ob. cit., p. te $^{\text {te }}$, p. 223. 
nial de aparato: ao $7.0^{\circ}$ dia da doença, desenganado pelos físicos, são afastadas da câmara mortuária a Rainha, a Infanta e o Príncipe, em parte, supomos, para se evitar o contágio da peste. Mas também por se começar a considerar que o rei devia morrer com a grandeza do seu estado e não como um pai de família, sujeito às emoçð̃es que a vista dos seus poderia provocar. Já há uma diferença notável: D. Afonso $\mathrm{V}$ é chefe de família que entrega ao seu filho as rédeas do governo (iríamos dizer, da sua casa); D. João II preside ao ritual, como rei e cristão. D. Manuel, como moribundo, é secundarizado: médicos e cortesãos (chefes de um protocolo) dirigem as cerimónias e ao rei é concedida uma intervenção condigna, mas não principal, como numa marcação cenográfica.

O préstito fúnebre segue até Belém. Damião de Góis concede a esta parte do cerimonial uma referência breve: «lágrimas, prantos e choros» (1), são as palavras empregues pelo cronista, o que condiz com as estrofes vicentinas.

Chegamos a D. João III. Morreu «algum tanto apressadamente» (de súpita e grave doença) mas recebeu os sacramentos. Há omissão quanto a sinais, quanto ao ritual da hora derradeira, quanto às presenças.

Assiste-se a uma mudança de mentalidade. Mais do que devido às causas acidentais (epidemia, D. Manuel; ou ataque súbito, D. João III), a privatização do acto da morte é substituída pelo empolamento do lado social: os funerais.

29. Os moribundos de sangue real dos séculos XV-XVI (com excepção das crianças, que têm a escusa da idade ou das mulheres em trabalho de parto) desempenham o principal papel no ritual mortuário. Conhecem a morte. Prevêm-na até. Porque além dos sinais próximos, que faziam parte do manual da morte, outros havia que Deus enviava aos eleitos. Encontra-se referência a esses avisos de dia e hora da morte, nas crónicas de Damião de Góis e Francisco de Andrada. Isto é, quando os sinais próximos estavam a ser relegados para segundo plano, há como que um processo compensatório que leva a atribuir aos moribundos régios uma graça de estado. Entra-se no maravilhoso da morte.

(1) Damião De Góis, ob. cit., p. te $4^{\text {a }}$. 
Um dos casos mais interessantes (embora cautelosamente temperado) desta mentalidade que, quase paradoxalmente, é renascentista, é a morte do Infante D. Duarte, filho de D. João III. Diz Francisco de Andrada: «....ele, ou fosse por revelação particular, ou pelo que em si sentia da sua enfermidade, disse a algumas pessoas que o fim de sua vida era chegado e declarou o dia em que havia de morrer, e se alguém lho contradizia, então o afirmava mais, no que veio a ser tão certo que aos onze dias da sua doença, vinte do mesmo mês de Outubro, que era o mesmo dia em que ele dissera que havia de morrer, o chamou o Senhor para si em idade de vinte e cinco anos....» (1).

Mas o maravilhoso não está só ligado à determinação da hora da morte (2), mas aos sucessos "post-mortem». O mesmo D. Duarte é objecto de uma hagiografia. Conta Francisco de Andrada: «Em um papel que me veio ter à mão feito por mestre André de Resende, homem de muitas letras e autoridades, que fora mestre do Infante D. Duarte, em que compendiosamente trata de muitas cousas particulares da sua vida, e da sua morte, de que ele diz que fora testemunha de vista, achei uma tão digna de espanto e ponderação que por ela ser tal e o autor grave e de muito crédito, me pareceu razão não passar sem dar relação dela. Diz que emparelhando o corpo do Infante com a porta do esprital [hospital] de Todos-os-Santos no rossio, se levantou da tumba em que o levavam uma pomba muito alva, sem haver pessoa que visse donde viera, e à vista de todos voara para o céu até desaparecer no ar, sem se poder atinar para onde fora, o que então por ser cousa tão nova e desacustumada pareceu geralmente que não carecia de mistério, porque aquele género de aves não costuma a voar de noite, nem voa direito para cima, e aquela pomba de si parece que se não devia de vir meter entre tanta multidão de gente e tamanha labareda de fogo, como então saía das tochas que ali estavam acesas»» (3).

Outro episódio, já muito conhecido, é a canonização feita por Damião de Góis do rei D. João II. Perante a incorruptibilidade do

(1) Francisco de Andrada, ob. cit., p. 223.

(2) Esta modalidade de previsão, segundo a terminologia de Platão denominava-se mântica e procederia da exaltação da alma, o que é diferente da oionística, em que o futuro é apreendido pela interpretação conjectural de sinais, Nesta, como vimos, não havia decifração porque se conheciam os sinais, constituindo indícios de um código estabelecido.

(3) FRANCisCo De ANDRADA, ob. cit., p. 802. 
corpo - e os «milagres» -, o humanista não hesita em considerar santo o Príncipe Perfeito (1).

30. Príncipes cristãos, como cristãos morriam, mesmo se tivessem prevaricado, infringido inclusive as leis de submissão ao seu rei. A hora derradeira ainda conservava, pelo menos, a virtude de constituir a última oportunidade. Veja-se a morte edificante de D. Fernando, duque (que fora) de Bragança.

Surge, pela pena dos insuspeitos Rui de Pina e Garcia de Resende, como o tipo de príncipe rebelde - o anti-herói por excelência - mas que, ao passar de réu a condenado, adquire a grandeza do mártir: invoca mesmo Cristo, como protótipo do inocente condenado. Quando o querem animar, já a caminho do cadafalso, para que não se chocasse com os clamores hostis da multidão, o duque responde: «Eu não me turvo, nem escandalizo do que me dizeis, porque, se o posso ou devo dizer, Jesus Cristo Nosso Senhor não morreu morte tão honrada» (2). Antes, tinha-se já recusado a comparecer à última sessão do julgamento. Mas D. Fernando não o faz (ou, pelo menos, não o invoca) por arrogância de grande senhor ou por fatalismo de condenado, mas em nome da sua qualidade de cristão que quer tratar, segundo as suas palavras: «....das cousas de minha alma e do outro mundo» (3). Garcia de Resende e, na sua esteira, Rui de Pina só acrescentam: «E não foi» (4). Desta sobriedade dos cronistas ressalta a admiração pelo homem que soube encarar a morte como cristão, que abdicou da avaritia, ele tão dado ao mundo e às suas pompas (5).

(1) Georges Duby estudou, para o espaço medieval francês, a "presença dos defuntos» e, nomeadamente, o poder taumatúrgico dos reis e a eficácia das relíquias. Vid. Georges Duby, L'an mil, Paris, Julliard, 1967.

(2) Garcia de ReSende, ob. cit., p. 69; RuI de Pina, ob. cit., p. 50.

(3) ReSENDE, ob. cit., p. 67; PINA, ob. cit., p. 48.

(4) Resende e Pina, Idem, ibid.

(5) «E certo o Duque recebeu a morte com tanta paciência, tanto arrependimento, e contrição de seus pecados, tanto esforço, e em tudo tão achegado a Deus, que muito se admiraram de tão santamente morrer, porque em sua vida não era havido como na morte se mostrou, antes por homem muito metido nas pompas e cousas deste mundo mais que nas do outro..., (GARCIA DE RESENDE, ob. cit., p. 70). Rui de Pina tem um discurso quase idêntico, mas com algumas variantes significativas: «... e verdadeiramente eu que o vi o testemunho e afirmo que o duque recebeu a morte com tanto arrependimento, e com tão esperta acusação de seus pecados, 
A execução - o seu ritual e protagonismo - assume um carácter expiatório que representa uma reformulação da mentalidade colectiva perante a morte do supliciado. Este, em plena Idade Média, era considerado uma criatura diabólica, já presa do inferno, embora a Igreja protestasse contra esta concepção e impusesse a presença do confessor junto ao carrasco. Bellarmin, no De arte bene moriendi, entende já que o condenado era reabilitado pelo sofrimento e a contrição. O suplício era o acto expiativo, tornando-se a morte do condenado muito mais meritória do que muitas mortes naturais.

31. A análise das narrativas dos cronistas dos séculos XV-XVI sobre a morte entre gente de sangue real, leva à conclusão de que a hora da morte tomava grande relevo na sensibilidade geral de meados/fins da Idade Média. Nos casos de D. Afonso V e de D. João II, o empolamento dado à hora do passamento é nítido: é o momento decisivo, em que o moribundo passa as provas e todos espiam atenta e ansiosamente o seu comportamento. Há como que uma satisfação dos íntimos perante a brilhante "performance» do ente querido.

A desvalorização da hora da morte começa a notar-se com D. Manuel, sendo já notável no caso de D. João III. Os desfiles, as quebras de escudos, os prantos - sobrevivência de antigos ritos, sem dúvida, mas considerados como projeç̧ão externa (social) da grandeza do Rei - sobrepõem-se ao intimismo da morte do cristão. Com o Renascimento, começa realmente o refluxo: aparentemente, tudo continua na mesma (artes moriendi, iconografia macabra nas residências) mas, sob essa permanência, uma desvalorização da advertência. D. Manuel presume-se que é advertido, não por graça divina mas pelos médicos e íntimos. De D. João III nem sequer consta que houvesse previsão: morte súbita, decerto, mas esse facto (ocultado até então por constituir um índice negativo) é registado com naaturalidade. O moribundo está a ser desapossado da sua morte, o protagonismo do último acto da vida do homem é transferido para o círculo dos próximos. Também começa a impôr-se uma outra concepção que concorre para

e com tanta paciência, e contrição, que quanto a Deus, e a ele, bem poderíamos como cristãos, chamar sua morte bem-aventurada: pois nela se viram mui claros sinais da verdadeira salvação de sua alma, e a que sua vida em cousas deste mundo revolta, parecia ser muito contraria» (RUI DE PINA, ob. cit., p. 50). 
o mesmo fim: não é no momento da morte que se deve pensar nela, mas durante toda a vida (o que é, aliás, defendido por Erasmo).

É certo que, incipientemente embora, Gil Vicente já se aproxima desta posição. A prestação de contas, imediatamente a seguir à morte, cifra-se no somatório dos actos que o homem praticou em vida (1). O diabo, nas Barcas, é o Ministério Público e, como acusador, tem um livro de contas, enquanto o anjo, quase impassível, espera que o réu se defenda. Digamos que o réu, ao invés das concepções jurídicas actuais, é sempre culpado, enquanto não demonstra a sua inocência. Na morte, em metáfora, de Mofina Mendes, vislumbramos as atenuantes para as suas culpas, mas ela não tem defensores entre os seus companheiros. Há um muro divisório entre réprobos e justos.

32. Ao atentarmos já não na morte de um príncipe de sangue, mas na de um grande guerreiro, evocado pela pena de Damião de Góis, apercebe-se o fim da vida não como momento decisivo, mas como hora de partida, esperada ou inesperada.

Afonso de Albuquerque - como o filósofo Canius que, condenado à morte, jogava xadrez quando o vieram. buscar para a execução morre tratando das cousas da India (que falavam por si «e por mim»). O final, na página do humanista, inculca uma sensação de grandeza, quase diríamos de mútua tolerância entre dois aliados: Afonso de Albuquerque e Deus. Albuquerque, magoado com a vida (os homens e o seu senhor terreno), pede a Deus dispensa de continuar cá em baixo. Logo sente a aproximação da morte e, como bom gestor, dá despacho às cousas materiais e espirituais. Com o seu confessor, pratica toda uma noite «nas cousas que cumpriam à salvação da sua alma» (2). Como parte desse "gentlemen's agreement» que o obriga a esperar, Deus só o chama quando o guerreiro está pronto para seguir viagem. Esta página de Damião de Góis revela-nos um mundo de desenganos (o tema do desconcerto não é só «leit-motiv» literário), mas no qual as relações homem-Deus se processam segundo um ritual pré-estabelecido. Não há revolta da criatura, mas acordo com o Criador.

(1) O Juízo final só mais tardiamente se afirma, com a ênfase dada ao Evangelho de S. Mateus.

(2) DAMIÃo DE Góls, ob. cit., p. ${ }^{\text {te }} 3 .^{\mathrm{a}}$, p. 287. 
33. Começámos esta volta pelos cronistas com a morte do rei-cavaleiro D. Afonso V, o Africano, e terminamo-la com a morte do conquistador da India. Ambos estes obreiros do Império (que polarizaram a sua acção em espaços físicos e mentais diferentes) anseiam pelo repouso do guerreiro. No percurso entre os dois, vimos, lentamente, o evoluir de uma mentalidade. A morte conjugada na 1. ${ }^{a}$ pessoa (D. João II); a morte oficializada (D. Manuel); a morte escamoteada (D. João III). Lentamente, vai-se caminhando para o pudor do momento da morte: porque a morte pertence à intimidade da pessoa, porque não é sempre exemplar (estética ou espiritualmente); porque, como já se disse, se impõe a noção de a morte se preparar em vida, não havendo uma «boa morte», mas uma «boa vida».

Acontece, porém, que o Renascimento vem acentuar, com a exaltação da glória dos feitos, a perpetuação do nome: a memória e a fama. Dá-se um retorno, em força, dos epitáfios; não que não houvesse, na Idade Média, esse testemunho da passagem de alguém por este mundo. Mas esse alguém era quase ninguém, porque o seu nome, quando constava da inscrição fúnebre, correspondia ao exemplo (abstracção, conceito), e não ao indivíduo. O morto funcionava, pois, como memento: para lembrar aos vivos o destino comum, não para proclamar as suas qualidades.

Neste contexto, o Epitáfio de Gil Vicente - a sua imagem do espelho - é memento mori. Com os epitáfios renascentistas, assistimos a uma metamorfose; passam a ser lembrança do outro: memento illius ( $\left.{ }^{1}\right)$.

(1) Em geral, esta expressão latina tem a sua aplicação plena nos «Lembrai-vos", nome genérico dado às pagelas mortuárias, última sobrevivência de uma atitude romântica perante a morte do ser querido. Era o memento a domicílio, em que a família do desaparecido atingia aqueles aos quais a ida à campa ou a leitura da notícia seriam momentos fugazes, ou nem sequer o seriam. Todavia, a mudança de agulhagem do sentido do eu para o ele processa-se em Quinhentos. Sobre este problema particular, os livros de PHILIPPE ARIÈs - Essais sur l'histoire de la mort en Occident du Moyen Age à nos jours, Paris, Seuil, 1975, e L'homme devant la mort, Paris, Seuil, 1977 - são, e continuarão a ser provavelmente por muito tempo, os guias insubstituíveis de quem quer que se debruce sobre o tema da morte. 


\section{A MORTE EM CAMÕES}

34. Problemas candentes dos anos 20-30 do século XVI - questão dos prognósticos e suas implicações, e guerras para a hegemonia europeia - estavam, senão em regressão, pelo menos em perda de velocidade quando Luís Vaz de Camões atinge o fim da adolescência. $O$ posicionamento de um Gil Vicente perante os problemas abordados não difereria muito daquele que impressionaria os estratos sociais com os quais o Camões menino e adolescente contactou. Questão de tónica ou de grau.

Mas, pela década de 40, Luíz Vaz de Camões, ao deixar a adolescência, deparou com um mundo que já não era aquele que encontrara ao vir à luz e nos primeiros anos e que o marcou - na sua problemática e na sua mentalidade - mas um mundo diferente, com novos problemas (ou apenas novas respostas e novas propostas para os mesmos problemas).

O sentido da morte e o ideal da vida eram (e serão sempre) os dois vectores da existência. Vimos a visão da morte em Gil Vicente e prolongámos essa visão até - para além da meta que nos tínhamos proposto - à adolescência de Camões. É a altura de dar a palavra ao génio da nossa poética.

A interpelação ao viandante, ao «homo viator», tópico literário latino cedo adaptado à cidade cristã, encontra-se presente no Epitáfio, de Gil Vicente. Há apenas transposição, o que é um recurso literário, do vocativo - «ó tu que passas» ou "ó viajante»-para "ó leitor». Está-se no ciclo da morte escrita na pedra ou no papel, e a terminologia tem de adaptar-se ao instrumento de comunicação. O tópico tinha-se, aliás, banalizado, como o demonstram composiçð̃es satíricas, no género da paródica invectiva de um clérigo, no Cancioneiro Geral, de Resende (1).

35. Das composições camonianas que se podem agrupar na categoria de epitáfios, destaque-se, em primeiro lugar, o soneto à sepultura de D. João III. O diálogo que se estabelece entre o viandante

(1) «.... vós outros qua passais / pelas vinhas, / respondei, assi vivais, / se vistes dores iguais / co[mo] as minhas!» (ANRIQUe DA Mota, comp. n. ${ }^{\circ}$ 796, "Cancioneiro Geral de Garcia de Resende», Coimbra, Centro de Estudos Românicos, vol. 2. ${ }^{\circ}$, p. 254). Trata-se da perda de uma pipa de vinho. 
e o panegirista põe a acentuação no aniquilamento: «Quem jaz no grão sepulcro, que descreve / tão ilustres sinais no forte escudo? / Ninguém, que nisso, enfim, se torna tudo...." (1). Estamos na linha de um niilismo que terá a sua máxima força na expressão funerária do século XVII, e mesmo do século XVIII. Não se trata de um niilismo, produto de cepticismo religioso, mas de uma visão da vida humana em termos de fragilidade, o que não contradiz a crença na vida além-túmulo (2). O soneto glosa um dos motes quase obrigatórios deste ciclo: o nemo ou o nihil.

Outro mote paralelo - umbra - é ilustrado pela Écloga I, à morte de D. António de Noronha (e também do príncipe D. João). Os onomásticos dos pastores, Umbrano e Frondélio, designam-nos como habitantes do reino das sombras. Neste reino, correm «as horas apressadas» ( $\left.{ }^{3}\right)$, tudo muda («como se vão as cousas convertendo / em outras cousas várias e inesperadas!» (4)): é a transitoriedade. Há dor: as lágrimas de Umbrano («de lágrimas me banha todo o peito»). O reino das sombras é «não o outro mundo, mas, sim, este mundo terrestre.... Das sombras e de sombra, ele mesmo» (5). Mundo de exílio, portanto, e apenas pálido reflexo da autêntica beleza. Percorrendo a lírica de Camões, encontram-se inúmeros exemplos da identificação sombra-terra de passagem / sem sombra-terra definitiva.

Esta leitura, todavia, não satisfaz plenamente. Há uma marcação de movimentos que pressupõe a existência de mais do que um espaço. Os pastores Umbrano e Frondélio falam dos vivos e dos mortos como habitantes de terras afins à sua, mas adivinha-se uma separação entre esses três espaços. Quando se levantam os clamores pela morte do príncipe D. João, eles permanecem em local de onde vêem, sem serem vistos: «Porém, irmão, melhor me parecia/ que não fossemos lá, que estorvaremos». As conotações imagísticas do «vale ameno e

(1) Lúís DE Camões, Obras completas, ed. Sá da Costa, vol. 1. ${ }^{\circ}$, Lisboa, 1971 , p. 218.

(2) A inscrição funerária do Cardeal Antonio Barberini reza assim: «Aqui jaz cinza, pó e nihil» (cit. de P. Ariès, L'homme devant la mort, p. 340). O historiador comenta: «Não se suspeitará de ateísmo o cardeal Antonio Barberini, morto em 1631, em plena Contra-Reforma e, no entanto, ele escolheu para o seu epitáfio romano essa mesma ideia que nos parece desesperada....» (Idem, ibid.).

(3) CAмÕES, Écloga I, in "Obras Completas», vol. $2 .^{\circ}$, p. 1.

(4) IDEM, ibid..

(5) Mário Martins, ob. cit., vol. 2., , p. 187. 
frio», por onde deambulam os pastores, atiram (talvez reminiscência não assumida) mais para além da vida terrena. Numa consonância idílica espaço-tempo, é lugar de inocência (locus amenus), numa era de harmonia (Idade de Ouro). Dado, porém, o clima funéreo, outras imagens surgem: os frescos prados virgilianos, banhados pelos riachos, para onde emigram os puros; os jardins prometidos pelo Corão aos crentes. E, principalmente, o lugar de repouso (1) florido que Turpin pede a Deus - «que Dieu reçoive toutes nos âmes dans les saintes fleures» - e ao qual Roland aspira - «en saintes fleures il le face gésir»: o locus refrigerii, sítio verdejante e tranquilo onde se aguarda o Juízo Final. Esta sugestão é acentuada pelo «túmulo de flores adornado» - em que não visionamos os ramos que hoje enfeitam as campas, mas as grinaldas, depostas ou esculpidas, que evocavam o refrigerium dos primeiros cristãos (2). Nesse túmulo, «o lasso caminhante» pousará a vista «lendo na pedra dura o verso escrito, / que diga assi: Memó-

(1) Através das épocas, o repouso na morte surge, quase invariavelmente, como desejável: "Dai-lhes, Senhor, o eterno descanso....", é jaculatória habitual nas preces pelos defuntos. Quando o lavrador vicentino da Barca do Purgatório chega ao cais de embarque para o outro mundo, o diabo (que, pelos vistos, tinha carência de mão de obra), pretende arregimentá-lo para manobras de levantar ferro. Responde o atribulado lavrador: «Da morte venho eu cansado / e cheio de refrigério....». Isto é, sente-se aliviado por já não ter de se esforçar, nem na vida, nem na hora da morte (essa hora vista como luta, dolorosa e extenuante como trabalho de parto). A vida que levou está expressa na célebre fala: «Nós somos vida das gentes, e morte das nossas vidas: / .... Que queira ser pecador / o lavrador: / não tem tempo nem lugar/nem somente de alimpar/as gotas do seu suor...." (G. Vicente, Auto da Barca do Purgatório, Obras Completas, Vol. 2. ${ }^{\circ}$, pp. 93-94). Vida em tudo semelhante à do lavrador gaulês a quem a morte se dirige nos seguintes termos: «Laboureur qui en soing et painne / avez vescu tout votre temps, / mourir faut, c'est chose certaine... / De mort deves estre contens / car de grant soussy vous délivre...» (cit. de P. ARIÈs, ob. cit., p. 119, extraída de uma Dança Macabra anterior ao século XVI, não especificada). MÁrio Martins (ob. cit., vol. 1. ${ }^{\circ}$, pp. 237-95), viu, com grande lucidez, a influência das Danças (de origem francesa) nas Barcas. Este texto não é, porém, referido. - Sobre a luta da hora da morte, no mesmo auto Gil Vicente mostra uma pastora-menina exausta dessa prova.

(2) A Igreja primitiva teve de proibir as práticas funerárias que lembravam os costumes pagãos. Flores, e até alimentos, eram depostos nos túmulos, como consolo dos mortos - e também para os conservar no seu sono, impedindo-os de vir perturbar os vivos. Santa Mónica ainda praticava esses ritos, antes da interdição de Santo Ambrósio. 
ria sou, / que grito / para dar testemunho, em toda parte, / do mais gentil esp'rito / que tiraram do mundo Amor e Marte!» (1).

No soneto (que se supõe consagrado a D. Gonçalo da Silveira), a obediência ao figurino convencional do género torna-se ainda mais flagrante, satisfazendo as três alíneas: interpelação ao viandante - «Não passes, caminhante!»; evocação dos feitos do morto - «.... De um que trocou finita e humana vida/ por divina, infinita e clara fama / ...QQuem derramar seu sangue não duvida/por seguir a bandeira esclarecida/de um capitão de Cristo, que mais ama»; injunção ao viandante para que divulgue os feitos - «.... Mais poderás contar a toda a gente / que sempre deu sua vida claro indício / de vir a merecer tão santa morte» (2).

36. Desde já se pode notar o passo dado na transformação de uma mentalidade - a visão da morte - dentro do mesmo século. Gil Vicente constrói o seu epitáfio segundo o figurino tradicional: a imagem do espelho - tu serás um dia aquilo que eu sou agora (3). Mas não pede ao viator (ou lector) que se recolha em oração pelo defunto ou que vá apregoar as suas virtudes. Não se está perante a solidariedade estreita que une cristãos de aquém e além-túmulo, nem perante o dever do homem que fica de perpetuar a vida ilustre do que partiu.

(1) Idem, p. 13. Nesta écloga, a par da celebração mortuária, há outro tema, como em pano de fundo: a antinomia Portugal passado/Portugal presente. $\mathrm{Na} 2 .^{\mathrm{a}}$ estrofe, o desabafo de Umbrano: «Eu já vi deste campo várias flores....", evoca esse pretérito idílico, para, na estrofe seguinte se apresentar a mudança operada, culminando o quadro com a sentença da 3.a estrofe: "Agora tudo está tão diferente.... O Tejo corre turvo e descontente, / as aves deixam seu suave canto....". Mas aqui estamos longe da visão da morte (pelo menos, no sentido directo) e perto de uma filosofia do desengano.

(2) CAMÕES, ob. cit., vol. $1 .^{\circ}$, p. 219 (soneto 58). O caminhante antecipa-se ao panegirista, exprimindo a sua admiração pelo que lhe é narrado e declarando: «Apregoando direi tão alta sorte $\left(1 .^{\circ}\right.$ terceto), sucedendo-se o reforço do narrador: "Mais poderás contar....». Embora seguindo o molde, o poeta procede a uma inversão das intervenções, de onde resulta um efeito de impacto mais conseguido.

(3) Cfr. MÁrio MARTINS, ob. cit., pp. 145-146, onde são transcritos epitáfios construídos sob o modelo do espelho. Alguns em latim, como o de Diogo Moniz ( $\dagger$ 1191): "Aspice, quia quod sum eris»; outros em português. Destes destacamos dois: "Ó tu que me vês aqui / cuida que al te verás. / Caveira me vês aqui, / se olhares para ti / mortal te conhecerás»; e outro (existente no Bussaco e encimado por caveira e tíbias): «Ó tu mortal, que me vês, / reflecte bem como estou: / Eu já fui o que tu és, / e tu serás o que eu sou». 
Gil Vicente insere-se no ciclo penitencial e não de sufrágio (e escassamente de homenagem). Note-se que o sufrágio tinha mais cabimento na inscrição funerária do que na expressão literária; em todo o caso, também certos letreiros exprimem, em verso ou em prosa harmoniosa e cadenciada, o pedido premente: «rezai por nós como desejaríeis que rezassem por vós» (1).

Os sonetos e a écloga de Camões testemunham já uma preocupação cada vez mais acentuada: a da sobrevivência terrena, que não exclui a celeste, mas de que não pode prescindir-se. Ideia não nova, repetimos, mas revalorizada. O ciclo arturiano tinha criado o mito do santo feudal, numa ligação, entre as duas imortalidades; o mito da cruzada quinhentista (contra o turco, contra o maometano do norte de África) não renega a sobrevivência escatológica, mas dá relevância à da memória: os mortos ilustres serão lembrados. Assim, Luís de Camões celebra D. Miguel de Menezes (Elegia VII) (2), D. Gonçalo da Silveira (um soneto) (3), D. Fernando de Castro (um soneto) (4), D. António de Noronha (Écloga I, e dois sonetos) (5), além do epitáfio a D. João III (6).

Entre estas composições (excluindo aquelas que já nos mereceram referência), destacamos a Elegia VIII, que, pertencendo embora à galeria heróica, tem modulações especiais. A cena da morte em combate é, simultaneamente, um quadro da escola maneirista e uma iluminura que acompanhasse uma canção de gesta. Da sintaxe pictórica maneirista tem a figuração alada (a Fama e os anjos), as estrelas abrindo

(1) O ciclo penitencial e o ciclo rogatório não se processam linearmente, mas por alternância, tanto quanto nos foi dado verificar, num trabalho que não visa essencialmente a análise das inscrições funerárias. Parece-nos que, na Idade Média, o tema do espelho (na linha das Danças Macabras) é o dominante: o cristão visa a salvação do próximo, servindo de exemplo; menos frequentemente, manifesta o seu desejo de ser sufragado. Porém, como as disposições testamentárias incluíam missas de sufrágio, e - acima de tudo - como a confiança em Deus, para o cristão que seguia as "artes moriendi», era grande, o epitáfio rogatório não era o dominante. $\mathrm{O}$ indivíduo passou a figurar em primeiro plano nas inscrições modernas, embora o processo viesse em marcha, e sempre em crescendo, desde os séculos XIV-XV, com a afirmação da crença no purgatório.

(2) Ver vol. 2. ${ }^{\circ}$ das Obras Completas, pp. 233-42.

(3) Vid. supra, p. 394.

(4) Vol. $10^{\circ}$, pp. 217-18.

(5) Vol. $2 .^{\circ}$, pp. 1-20; vol. 1.॰, p. 218.

(6) Vol. 1. , pp. 217-18. 
em cada chaga do guerreiro e o mausoléu com a inscrição. Sobretudo, a coexistência de dois planos: a terra onde o cavaleiro jaz e o céu para onde ergue os olhos. A Elegia VIII é sempre movimento oscilatório na vertical.

Mas é também a morte de Olivier ou de Roland. D. Miguel, desfalece «.....pedindo dos erros que na idade / verde e quase inocente já fazia / perdão à pia e justa Majestade». E Roland, batendo no peito, murmura: «.... Dieu, mea culpa, par ta puissance, pour les péchés, grands et menus, que j'ai commis depuis l'heure où je suis né jusqu'à ce jour où je suis frappé à mort». D. Miguel, «nas mãos do coro angélico, que dece, se entrega e vai gozar a vida eterna». O mesmo sucede com Roland: "Les anges du ciel descendent vers lui» (1). D. Miguel de Menezes, como Roland, morre na guerra contra o infiel, com contrição dos pecados e merecendo ser conduzido ao céu pelos anjos. O retrato do jovem guerreiro contém ainda dois outros elementos típicos da mentalidade da época: a glória dos maiores, ou seja, a honra como inerência da estirpe; os dotes físicos, e a juventude, como factores insólitos numa associação com a morte. Compete ao poeta ser o celebrante dos esponsais da glória com a morte e da beleza-juventude com a mesma morte. Só assim o holocausto terá sentido porque será eternizado.

Mas se Eros-Thanatos já preside a estas comemorações, porque o herói amou, essa união vai avultar mais, como é óbvio, nas homenagens derradeiras prestadas à mulher - a amada do poeta ou apenas o ser de beleza, que a um poeta repugna ver na terra. Porque em Camões o sentimento expresso nos sonetos à memória de Dinamene, de D. Maria de Távora, de Catarina de Ataíde, ou de alguma mulher não nomeada, é o ciúme. Ciúme da morte, que é o rival que goza eternamente o belo corpo da amada: os seus cabelos, os seus olhos. Todavia, ele (o poeta, o amante) espera uma união além-túmulo ( $A$ lma minha gentil), mas logo se lamenta (Cara minha inimiga) do poder da morte («eternamente as águas lograrão / a tua peregrina fermosura»).

(1) O tema é retomado na estrofe seguinte, em processo repetitivo, com efeito de ênfase, de uso nas canções de gesta. KK....il bat sa coulpe et demande à Dieu merci: 'Vrai Pére, qui jamais ne mentis, qui ressuscitas des morts saint Lazare et sauvas Daniel des liones, sauve mon âme de tous les périls, pour les péchés que j'ai fait en ma vie! .... Dieu lui envoie son ange chérubin et saint Michel du Péril: avec eux y vint saint Gabriel. Ils portent l'âme du comte en paradis». 
É a eterna violação, que o poeta tenta afastar do pensamento pela afirmação (compensatória) de que o espírito lhe pertence («porque celebrada serás sempre em meu canto....»). O ciúme está presente no soneto Ah! minha Dinamene!, revestindo a forma de uma acusação: a amada deixou-o, desprezou a vida, magoou-o, consentiu que a morte a possuísse («Nem falar-te somente a dura Morte / me deixou, que tão cedo o negro manto / em teus olhos deitado consentiste»). Sob a ficção poética, vislumbram-se as imagens eróticas inspiradas pela paixão. Os românticos irão trabalhar este tema, mas nos séculos XVI e XVII a imagem Eros-Thanatos possue, ao mesmo tempo, o pudor e a volúpia, sem as concessões à sensibilidade (sensiblerie) mórbida.

37. Das restantes composições camonianas do ciclo da morte (por pouco adiantarem a uma leitura de história das mentalidades), faremos apenas breves referências, detendo-nos um pouco numa leitura global. O soneto que se inicia segundo o tipo do epitáfio dialogado, pela interrogação "Que levas, cruel Morte?» (a ser de Camões, e, se o não for, obedece ao padrão da época - o que, no nosso estudo, é primordial) faz ressaltar a antinomia entre a beleza e a ausência dela, sendo de destacar o verso "Seu corpo quem o goza? - A terra fria». O soneto "Chorai, ninfas, os Fados poderosos» glosa o mote: o mundo não merece as pessoas perfeitas, de corpo e espírito (ideia também expressa na composição anterior). E há a visão, em sonhos, da que foi sonho em vida (Quando de minhas mágoas a comprida). Também ao ciclo de Amor e Morte pertence o soneto aos dois noivos ceifados pelas Parcas: «Ditosas almas, que ambas juntamente / ao céu de Vénus e de Amor voastes, / onde um bem que tão breve cá lograstes / estais logrando agora eternamente....». Através da visão poética, persiste a ideia de uma continuação dos afectos terrestres na pátria celeste.

Uma última consideração nos impõe o tópico. Embora não de maneira explícita, o poeta, por vezes, na sua expressão de revolta contra a morte que arrebata jovens belas (belos), manifesta, a par de um sentimento de expoliação sofrido, a angústia perante o desfazer da beleza. É, não nitidamente expresso, o horror da decomposição, o desaparecimento do ser amado ou do amigo querido: a imagem de um não-ser físico e a imagem do nihil. Essa ideia que, na visão medieval, levava a uma tomada de consciência, no sentido de um contemptus 
mundi (1), assume agora, mesmo para o crente (excluímos o asceta, por excepcional), um estremecimento de horror. Horror pela decomposição em si, horror pelo nada. A esta angústia, ele tenta escapar pela imortalidade do nome: o homem que viveu nesta terra é nela que tem de perdurar. Não se nega, com isto, a imortalidade do espírito. Mas o homem do mundo moderno, no seu individualismo, pretende uma duplicação de imortalidade entre os homens.

\section{MENTALIDADES EM MUDANÇA}

38. Gil Vicente e Camões pertencem a geraçð̃es diferentes, que são sempre mundos diferentes. $\mathrm{Na}$ sua visão da morte existem, como se disse, perspectivas que não coincidiam. Quase nada parecia ter-se alterado e, todavia, entre a morte conjugada na $1 .^{\mathrm{a}}$ pessoa e a morte do outro não há apenas mudança de tónica, mas de mentalidade.

Também, na visão da vida - na vida, como um ideal - ambos vêem no campo o oásis de paz e simplicidade (apetecido mas não procurado) (1). Mestre Gil lê o campo em termos de passado: de retorno aos bons velhos tempos. Luis Vaz de Camões, renascentista, projecta nele o milenarismo laico: é a Idade de Ouro, de uma pastorícia clássica, que o desencanto da curialização arrasta consigo.

Pastores vicentinos e pastores camoneanos estão, pelo menos aparentemente, muito distantes. Os primeiros são extraídos do real: o seu mundo é um pedaço do real, mas um pedaço seleccionado, note-se. Os pastores de Camões, inseridos na convenção bucólica, são «tra-

(1) Lembrar as considerações de D. João II, nas últimas horas de vida: «Não me chameis Alteza, que não sou senão um saco de terra e de bichos» (GARCIA DE Resende, Crónica de Dom João II e Miscelânea, ed. Imprensa Nacional - Casa da Moeda, Lisboa, 1973, p. 284).

(1) Em termos literários, o «romantismo» pastoral já se anunciava, sob forma episódica, no romance de cavalaria. Em Portugal, o Amadis é o protótipo ou o manual das virtudes do bom cavaleiro: intrépido, bom cortesão, mas, pela aventura, escapando à vida estática da corte. Na Menina e Moça, 2.a parte, também já se exprime a nostalgia de gentis homens e damas que sonham uma vida campestre que a distância embeleza. A parte 1. ${ }^{a}$ (indubitavelmente de Bernardim) está na linha de fronteira entre a novela pastoril-cavaleiresca e a novela de sentimento, como bem se tem dito, mas contém, em germe, os mesmos elementos de evasão. Ver, a este propósito, a obra de Norbert Elias, La société de cour, Paris, Calman-Lévy, 1974. 
vestis», máscaras do homem urbanizado e curializado. Numa palavra, são a personificação das frustraçðes do homem em desacordo com a Natureza, mas sentindo a sua actracção nostálgica. Para ele, o passado transforma-se numa visão de sonho, aparecendo a vida no campo como o símbolo da inocência perdida, da simplicidade livre e natural, em oposição à vida de corte - mais diversificada, mais rica em relações humanas, mas sujeita aos constrangimentos, às obrigaçð̃es hierárquicas complicadas, ao controlo próprio. Mas, no século XVI adiantando a que Luís de Camões pertence, a curialização de parte da nobreza (mesmo da velha nobreza de espada) já tinha feito tais progressos que homens e mulheres da corte não teriam certamente apreciado regressar à vida relativamente primitiva dos seus antepassados. O refúgio na ficção - e quanto mais idealizada a ficção, melhor - é sonho compensatório, é «acting out» dos cortesãos. A esta visão, juntem-se os fetiches do prestígio: a glória, a honra, a fama - facetas de um mesmo imaginário, ou elementos de uma semântica da corte. Facetas essas que ainda não eram evidentes num Gil Vicente, preocupado antes com uma fixação à terra, princípio sagrado que uma Mofina põe em questão e que mestre Gil amarra, por isso, ao pelourinho da irrisão geral. O seu grito de revolta torna-se grito de truão. Mofina é D. Truana e o truão vive no mundo fictício, onde tudo é possível. Esta a moralização de mestre Gil. À evasão pelo progresso quer contrapor a evasão pelo regresso, mas as pessoas não são personagens e as pegureiras vieram até à cidade.

GraÇa Silva Dias 